\title{
Endogenous Minerals Conditioned Genotypic Variation of Phytochemicals in Broccoli Leaves under Salinity Stress
}

\author{
Chokri Zaghdoud*, Mohamed Bagues, Yassine Yahia, Kamel Nagaz \\ Dry Land Farming and Oasis Cropping Laboratory, Institute of Arid Regions of Medenine, University of Gabes, \\ Medenine 4119, Tunisia
}

Received: 6 June 2020

Accepted: 18 August 2020

\begin{abstract}
Here, changes in the leaf mineral composition of broccoli (Brassica oleracea L. var. italica Plenck) plants in response to single and interactive two-week salt $(0,30,60$ and $90 \mathrm{mM} \mathrm{NaCl})$ exposure and cultivar (cvs. Parthenon and Naxos) factors were studied, as well as their correlations with individual glucosinolates (GSLs), vitamin $\mathrm{C}$ and total anthocyanins. Results showed significant differences in micro- $\left(\mathrm{Fe}^{2+}, \mathrm{Cu}^{2+}, \mathrm{Zn}^{2+}, \mathrm{Mn}^{2+}\right.$ and $\left.\mathrm{B}^{3+}\right)$ and macroelements $\left(\mathrm{S}, \mathrm{N}, \mathrm{C}, \mathrm{NH}_{4}^{+}\right)$contents regarding the studied factors and/or their interaction. Salinity effects on individual GSLs showed contradictor behaviours between both cultivars, being the increase in aliphatics in Parthenon negatively correlated with $\mathrm{Mn}^{2+}$ ions, while the decrease in indolics in Naxos related positively with $\mathrm{N}$ and N/S ratio and negatively with $\mathrm{NH}_{4}^{+}$content $(P<0.01)$. Interestingly, only in $\mathrm{cv}$. Naxos all bioactive compounds displayed a strong relationship with $\mathrm{Zn}^{2+}$ ions, majorly negative. Stress intensity-dependant reductions in vitamin $\mathrm{C}$ and total anthocyanin levels in both cultivars were caused by differential endogenous $\mathrm{NH}_{4}^{+}$ions accumulation, reflecting co-participation of these compounds in the leaf antioxidant capacity. Overall, in salt-affected lands, a clear genotypic dependence of broccoli plants regarding endogenous leaf minerals was recorded, influencing individual GSLs, vitamin C and total anthocyanin profiles.
\end{abstract}

Keywords: broccoli cultivars, correlation, minerals, phytochemicals, salinity

\section{Introduction}

Soil salinisation is one of the major abiotic factors limiting agricultural productivity worldwide [1, 2]. Salt stress may occur in areas where soils are naturally high in salts and/or where irrigation with salty underground water brings salt to the surface soil that plants inhabit

*e-mail: chokri_zaghdoud@yahoo.fr
[3]. In glycophytic plants, salinity can induce nutritional disorders as a result of its osmotic effect, which is equivalent to a decrease in water activity through specific toxic effects of $\mathrm{Na}^{+}$and $\mathrm{Cl}^{-}$ions [4, 5]; thus, reducing their growth [6]. In addition, it also manifested an oxidative stress [7]. However, the microelements are generally less affected by salt stress compared with macroelements because of the fact that they are required in much smaller quantities [8,9], even though different ideas related to their tendency of variation are 
proposed. Thus, depending on plant species, the uptake of some microelements was promoted [10], inhibited [11] or unaffected [12] by salinity stress. This saltinduced ionic stress caused in plants alterations in nitrogen $(\mathrm{N})$ and carbon $(\mathrm{C})$ metabolism, leading to adaptive changes in growth and physio-biochemical processes [13-15].

The first natural adaptation response to both ionic and osmotic stress under salinity is the accumulation of osmo-protectants in plant cells, with possible marked effect on secondary metabolites production [16]. In fact, macroelements such as sulfur (S), C and $\mathrm{N}$ have particular relevance for secondary metabolites biosynthesis, while microelements availability may impact production of bioactive compounds through effect(s) on biosynthetic pathways as activators of enzymes [17]. Among the bioactive compounds as adaptive component of salt tolerance, Glucosinolates (GSLs) are involved in osmotic adjustment under low water potential [18]. GSLs are a class of $\mathrm{N}$ and sulfur (S) containing compounds mainly found in Brassica crops, with health promoting properties [19, 20]. Although their specific functions are still not completely clarified, GSLs response to salt stress largely depended on the experimental conditions, the type of GSL and the plant genotype [21]. Another phytochemicals that plays an inductive role in attenuating the adverse effects of salinity on plant growth and metabolism are vitamin $\mathrm{C}$ (nutritional antioxidant including both reduced and oxidized forms, ascorbic acid (AA) and dehydroascorbic acid (DHAA), respectively) [22] and anthocyanins (nonnutritional antioxidants) [23]. They are incorporated in the detoxification and neutralization of reactive free radicals, thereby protecting cells from oxidative damage [24, 25]. Under salinity, significant reduction in the vitamin $\mathrm{C}$ level was observed [26, 27], due to its implication in the enhancement of ascorbate peroxidase activity, thereby participating in $\mathrm{H}_{2} \mathrm{O}_{2}$ reduction [28, 29]. In contrast, anthocyanin level was reported to increase in response to salt stress [30, 31], but only in the salt-sensitive species when it was decreased [32].

Broccoli (Brassica oleracea L. var. italica Plenck) is a cruciferous vegetable rich in minerals and bioactive compounds [33]. Available studies in the literature describing effects of genotype-environment interaction (GEI) on the nutrient and phytochemical profiles in broccoli are focused in the inflorescences as edible parts. However, limited information is available regarding how changes in the mineral composition of broccoli leaves under GEI could affect their phytochemical profile. In fact, vegetable by-products are potentially used as a source of bioactive compounds [34, 35]. Therefore, the aim of the study was to determine the micro- and macroelement composition of broccoli leaves under single and combined effects of salinity and cultivar factor, and to assess their correlations with individual GSLs, vitamin $\mathrm{C}$ and total anthocyanins concentrations.

\section{Material and Methods}

\section{Plant Growth and Experimental Design}

Seeds of broccoli (Brassica oleracea var. italica, cvs. Parthenon and Naxos, differing in their culture cycle) were pre-hydrated with de-ionised water and aerated continuously for $12 \mathrm{~h}$. Then, the seeds were germinated in vermiculite, in the dark at $28^{\circ} \mathrm{C}$, for 2 days. The seedlings obtained were transferred to a growth chamber at $25^{\circ} \mathrm{C} / 60 \%$ relative humidity $(\mathrm{RH})$ during the light period and $20^{\circ} \mathrm{C} / 80 \% \mathrm{RH}$ during the dark period, with a photoperiod of $16 \mathrm{~h}$ daily with a light irradiance of $400 \mu \mathrm{mol} / \mathrm{m}^{2} / \mathrm{s}$ at the plant canopy, provided by a combination of fluorescent tubes (TLD36W/83, Philips, Hamburg, Germany and F36W/ GRO, Sylvania, Danvers, MA, USA) and metal-halide lamps (HQI, T 400W; Osram, München, Germany). After three days, the seedlings were separated to groups of ten per 15-L container with continuouslyaerated nutrient solution [36], replaced weekly. After 15 days of growth, plants were separated to five per container, and the salinity treatment $(0,30,60$ and $90 \mathrm{mM} \mathrm{NaCl}$ ) was supplemented to the nutrient solution for two weeks. Five independent set of experiments were used for the determinations. For each experiment, a Split-Plot design, with two factors $(\mathrm{NaCl}$ treatment, cultivar) and five replications, was used, to analyse each physiological variable. Plants were 32 days-old when they were harvested for analysis.

\section{Mineral Elements and Ammonium Contents}

The analyses of iron $\left(\mathrm{Fe}^{2+}\right)$, copper $\left(\mathrm{Cu}^{2+}\right)$, zinc $\left(\mathrm{Zn}^{2+}\right)$, manganese $\left(\mathrm{Mn}^{2+}\right)$, boron $\left(\mathrm{B}^{3+}\right)$, sodium $\left(\mathrm{Na}^{+}\right)$, potassium $\left(\mathrm{K}^{+}\right)$and sulfur $(\mathrm{S})$ were carried out after $\mathrm{HNO}_{3}-\mathrm{HClO}_{4}(2: 1)$ acid digestion of the oven-dried leaf samples (ca. $0.1 \mathrm{~g}$ of dry weight, DW). Each was determined by inductively coupled plasma spectrometry (OES Thermo ICAP 6000 Series $^{\circledR}$, Thermo Electron Corp., Franklin, MA, USA) in a dilution with $\mathrm{LaCl}_{3}+\mathrm{CsCl}$ of the extract aliquot, as reported elsewhere [37]. A Thermo FlashEA 1112 autoanalyser (Thermo Fisher Scientific SA, Madrid, Spain) was used for the determination of total carbon (C) and nitrogen $(\mathrm{N})$ in the samples.

The ammonium $\left(\mathrm{NH}_{4}^{+}\right)$was extracted from plant material at $4^{\circ} \mathrm{C}$ with $0.3 \mathrm{mM} \mathrm{H}_{2} \mathrm{SO}_{4}$ and $0.5 \%$ (w/v) polyclar AT. The $\mathrm{NH}_{4}^{+}$concentration was quantified according to the Berthelot reaction, as modified by Weatherburn [38]. The mineral elements and $\mathrm{NH}_{4}^{+}$ contents were expressed as $\mathrm{mmol} / \mathrm{Kg} \mathrm{DW}$.

\section{Intact Glucosinolates and Vitamin C Contents}

Glucosinolates, AA and DHAA were analysed according to the procedures described by Zaghdoud 
et al. [39]. The vitamin $C$ content was calculated by adding together the AA and DHAA contents. Individual GSLs and vitamin $\mathrm{C}$ concentrations were expressed as $\mathrm{mg} / \mathrm{g}$ DW.

\section{Total Anthocyanin Content}

Total anthocyanin content was measured according to the method described by Fuleki and Francis [40]. Lyophilised leaves (1 g) finely ground by mortar and pestle were extracted with acidified ethanol (85:15 of $95 \%$ ethanol: $1.5 \mathrm{M} \mathrm{HCl}$ ) and allowed to sit with occasional mixing for $72 \mathrm{~h}$ at $4^{\circ} \mathrm{C}$. The crude extracts were then centrifuged at $10,000 \times g$ for $15 \mathrm{~min}$ at $4^{\circ} \mathrm{C}$. Supernatant was collected, diluted 10 times, and its absorbance measured at $535 \mathrm{~nm}$ using UV-visible spectrophotometer. Cyaniding 3-galactoside was used as an external standard. Anthocyanin content was calculated using the following equation:

$$
\begin{gathered}
\text { Total anthocyanins }(\mathrm{mg} / \mathrm{g} \mathrm{DW}) \\
=\left(A_{535 \mathrm{~nm}} \times 10\right) / 98.2
\end{gathered}
$$

...where: 10 is the dilution factor, $\mathrm{mL} ; 98.2$ is the absorbance coefficient of cyaniding 3-galactoside.

\section{Statistical Analysis}

The data were analysed statistically using the SPSS 18.0 software package (SPSS Inc., Chicago, IL, USA). Within each independent set of experiments used for the determinations, means of the five repetitions were considered as true one replication. Mean values for each studied physiological parameter, within each treatment, were calculated from the five independent experiments $(\mathrm{n}=5)$. Analysis of variance (ANOVA) was used, and the mean values were compared by a one-way ANOVA/Tukey's multiple comparison (at $P<0.05$ ). Two-way ANOVAs were used to estimate whether salinity or cultivar factors, applied individually or in combination, had a significant influence on the mean values (at $P<0.05, P<0.01$ and $P<0.001$ ). For each broccoli cultivar, Pearson correlation analysis was used to test the relationships between levels of individual glucosinolates, vitamin $\mathrm{C}$ and total anthocyanins against micro- and macronutrients contents.

\section{Results}

\section{Trace Elements and Mineral Nutrients}

Results of the analyses of essential trace elements (Fe, $\mathrm{Cu}, \mathrm{Zn}, \mathrm{Mn}$ and $\mathrm{B}$ ) in leaves of cvs. Parthenon and Naxos are shown in Table 1. From the studied factors, the Fe level was influenced only by $\mathrm{NaCl} \times \mathrm{Cultivar}$ interaction $(P<0.05)$, due to differential effects of low and high $\mathrm{NaCl}$ treatments in cv. Naxos. Regarding untreated plants, copper content increased at middle $\mathrm{NaCl}$ concentration $(60 \mathrm{mM})$ in $\mathrm{cv}$. Naxos and at high concentration $(90 \mathrm{mM})$ in $\mathrm{cv}$. Parthenon leading to significant $(P<0.05) \mathrm{NaCl} \times$ Cultivar influence. The $\mathrm{Zn}$ and $\mathrm{Mn}$ contents were significantly affected by salt stress $(P<0.001)$, cultivar factor $(P<0.01)$ and their interaction $(P<0.001)$. Thus, only in cv. Naxos, Zn content was gradually increased with increasing salinity, reaching

Table 1. Trace elements (iron $\left(\mathrm{Fe}^{2+}\right)$, copper $\left(\mathrm{Cu}^{2+}\right)$, zinc $\left(\mathrm{Zn}^{2+}\right)$, manganese $\left(\mathrm{Mn}^{2+}\right)$ and boron $\left.\left(\mathrm{B}^{3+}\right)\right)$ contents $(\mathrm{mmol} / \mathrm{Kg} \mathrm{DW})$ in the leaves of broccoli plants grown for two weeks under saline conditions $(0,30,60$ or $90 \mathrm{mM} \mathrm{NaCl}$ ) differentiating between cultivars (cvs. Parthenon and Naxos). Data are means \pm SE $(n=5)$. Means within a column followed by a different lower-case letter are significantly different according to Tukey's test at $P<0.05$. Individual and combined effects of the two factors (salinity, cultivar) are given according

\begin{tabular}{|c|c|c|c|c|c|c|}
\hline \multirow{2}{*}{ Cultivar } & \multirow{2}{*}{$\mathrm{NaCl}[\mathrm{mM}]$} & \multicolumn{5}{|c|}{ Trace elements } \\
\hline & & $\mathrm{Fe}^{2+}$ & $\mathrm{Cu}^{2+}$ & $\mathrm{Zn}^{2+}$ & $\mathrm{Mn}^{2+}$ & $\mathrm{B}^{3+}$ \\
\hline \multirow{4}{*}{ Parthenon } & 0 & $1.22 \pm 0.03 \mathrm{ab}$ & $0.053 \pm 0.002 \mathrm{ab}$ & $1.79 \pm 0.11 \mathrm{~b}$ & $1.40 \pm 0.10 \mathrm{~cd}$ & $3.55 \pm 0.09 \mathrm{bc}$ \\
\hline & 30 & $1.20 \pm 0.04 \mathrm{ab}$ & $0.053 \pm 0.001 \mathrm{ab}$ & $1.72 \pm 0.08 \mathrm{ab}$ & $1.39 \pm 0.06 \mathrm{bcd}$ & $3.70 \pm 0.05 \mathrm{c}$ \\
\hline & 60 & $1.24 \pm 0.05 \mathrm{ab}$ & $0.054 \pm 0.001 \mathrm{ab}$ & $2.19 \pm 0.10 \mathrm{~b}$ & $1.10 \pm 0.07 \mathrm{abc}$ & $3.70 \pm 0.08 \mathrm{c}$ \\
\hline & 90 & $1.25 \pm 0.05 \mathrm{ab}$ & $0.060 \pm 0.004 \mathrm{~b}$ & $2.10 \pm 0.16 \mathrm{~b}$ & $0.81 \pm 0.06 \mathrm{a}$ & $3.55 \pm 0.11 \mathrm{bc}$ \\
\hline \multirow{4}{*}{ Naxos } & 0 & $1.22 \pm 0.03 \mathrm{ab}$ & $0.050 \pm 0.001 \mathrm{a}$ & $1.16 \pm 0.03 \mathrm{a}$ & $1.02 \pm 0.05 \mathrm{a}$ & $3.06 \pm 0.10 \mathrm{a}$ \\
\hline & 30 & $1.29 \pm 0.02 \mathrm{~b}$ & $0.050 \pm 0.000 \mathrm{a}$ & $1.92 \pm 0.09 \mathrm{~b}$ & $1.52 \pm 0.09 \mathrm{de}$ & $3.18 \pm 0.09 \mathrm{ab}$ \\
\hline & 60 & $1.30 \pm 0.02 \mathrm{~b}$ & $0.061 \pm 0.001 \mathrm{~b}$ & $2.81 \pm 0.09 \mathrm{c}$ & $1.75 \pm 0.03 \mathrm{e}$ & $3.42 \pm 0.10 \mathrm{abc}$ \\
\hline & 90 & $1.13 \pm 0.04 \mathrm{a}$ & $0.054 \pm 0.002 \mathrm{ab}$ & $3.06 \pm 0.21 \mathrm{c}$ & $1.07 \pm 0.09 \mathrm{ab}$ & $3.13 \pm 0.08 \mathrm{a}$ \\
\hline \multirow{3}{*}{$\begin{array}{l}\text { Source of } \\
\text { variance }\end{array}$} & $\mathrm{NaCl}$ & n.s & $* *$ & $* * *$ & $* * *$ & $*$ \\
\hline & Cultivar & n.s & n.s & $* *$ & $* *$ & $* * *$ \\
\hline & $\mathrm{NaCl} \times$ Cultivar & * & * & $* * *$ & $* * *$ & n.s \\
\hline
\end{tabular}
to ANOVA tests, with significance expressed as follows: * at $P<0.05 ; * *$ at $P<0.01$; *** at $P<0.001$; n.s.: non significant. 


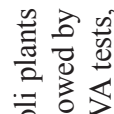

훙 응

형

os

⿷匚

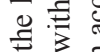

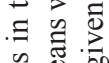

串

iิ

艺的吾

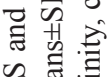

$\Sigma$ 鹿

文密

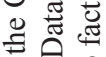

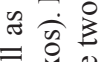



क

ㅎํㅇ

施

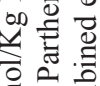

苜它

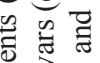

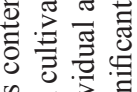

을 릉

F

乙范守

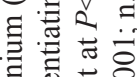

这苍

羊舟

氙氞节*

б) $\sum_{00}^{\circ} \ddot{0}$

ठี है

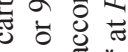

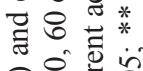

乏帒离

e

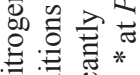

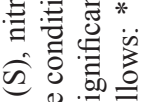

音要

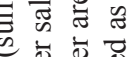

乐完离

敋

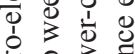

总主言芯

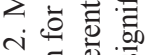

$N$ 政

语高害青

\begin{tabular}{|c|c|c|c|c|c|c|c|c|c|c|}
\hline 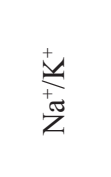 & $\begin{array}{l}0 \\
0 \\
0 \\
0 \\
0 \\
0 \\
0\end{array}$ & $\begin{array}{l}0 \\
0 \\
0 \\
0 \\
0 \\
11 \\
0 \\
0 \\
0\end{array}$ & \begin{tabular}{c|c}
0 & \\
$\infty$ & \\
0 & \\
0 & \\
+1 & \\
$\infty$ & \\
&
\end{tabular} & 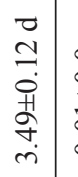 & 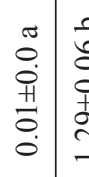 & 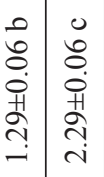 & 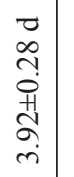 & * & * & $\stackrel{\mathscr{L}}{=}$ \\
\hline$\frac{n}{z}$ & 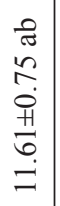 & 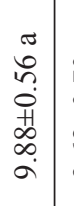 & 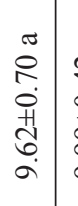 & \begin{tabular}{l}
$\tilde{\sigma}$ \\
\multirow{\jmath}{0}{} \\
0 \\
$\ddot{1}$ \\
$\alpha$ \\
$\sigma$
\end{tabular} & 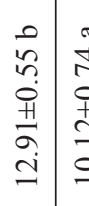 & 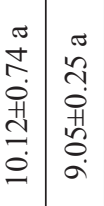 & 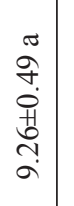 & $\underset{*}{*}$ & $\stackrel{n}{=}$ & $\stackrel{n}{=}$ \\
\hline z & 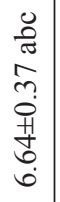 & 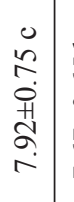 & $\begin{array}{l}0 \\
0 \\
n \\
0 \\
+1 \\
\vdots \\
\dot{0} \\
r\end{array}$ & $\begin{array}{l}0 \\
\tilde{n} \\
0 \\
⿱ 艹 \\
\tilde{n} \\
\infty\end{array}$ & 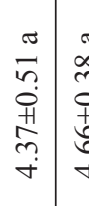 & 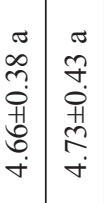 & 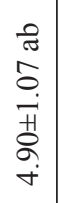 & $\stackrel{n}{=}$ & $\begin{array}{l}* \\
* \\
*\end{array}$ & $\stackrel{n}{=}$ \\
\hline $\mathbf{z}^{+}$ & 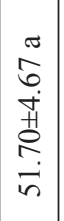 & 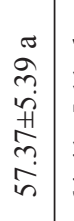 & 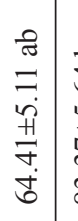 & 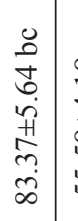 & 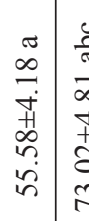 & 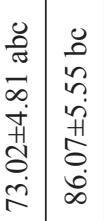 & $\begin{array}{l}0 \\
i \\
\infty \\
0 \\
0 \\
b \\
\dot{0} \\
\dot{a}\end{array}$ & * & $*$ & $\stackrel{n}{=}$ \\
\hline \multirow{3}{*}{ 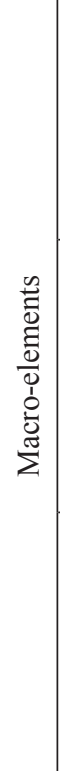 } & 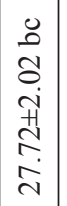 & 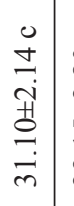 & 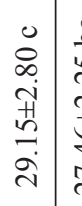 & 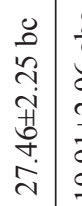 & 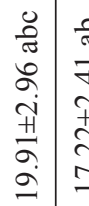 & 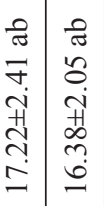 & $\begin{array}{l}\tilde{\sigma} \\
\infty \\
\tilde{n} \\
\tilde{n} \\
\tilde{n} \\
\tilde{n}\end{array}$ & $\stackrel{\leftrightarrow}{g}$ & * & $\stackrel{n}{=}$ \\
\hline & $\begin{array}{l}0 \\
0 \\
0 \\
0 \\
0 \\
+1 \\
= \\
+ \\
+\end{array}$ & 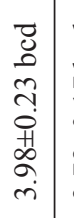 & 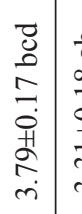 & 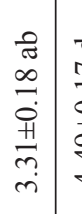 & 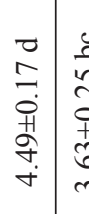 & 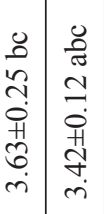 & 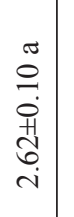 & * & * & * \\
\hline & 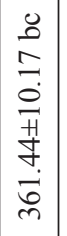 & 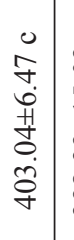 & 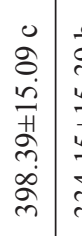 & 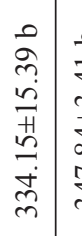 & 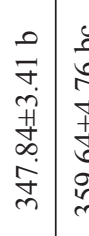 & 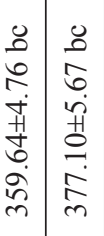 & 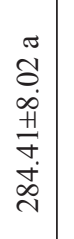 & * & * & $\stackrel{\curvearrowleft}{=}$ \\
\hline 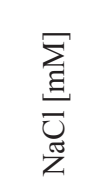 & 0 & i & 8 & ฉ & 0 & i) 8 & 8 & $\begin{array}{l}\overline{\tilde{z}} \\
\ddot{z}\end{array}$ & U & 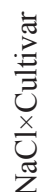 \\
\hline 胥 & & 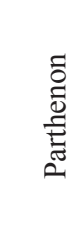 & 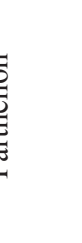 & & & $\begin{array}{l}\text { o } \\
0 \\
\text { ž }\end{array}$ & & & 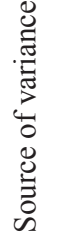 & \\
\hline
\end{tabular}


2.64-fold the control values at $90 \mathrm{mM} \mathrm{NaCl}$. Regarding Mn accumulation, contrasting results were found between the two cultivars under $\mathrm{NaCl}$ stress: the values were significantly decreased only in cv. Parthenon (by $42.14 \%$ at $90 \mathrm{mM}$ ), while they increased in cv. Naxos at 30 and $60 \mathrm{mM}$ (by $49.02 \%$ and $71.57 \%$, respectively). Significant differences between the cultivars $(P<0.001)$ were also observed for B content, depending with salinity treatment $(P<0.05)$, being the levels lower in $\mathrm{cv}$. Naxos than in cv. Parthenon (except for $60 \mathrm{mM} \mathrm{NaCl}$ ).

Sulfur (S), nitrogen (N), carbon (C) and ammonium $\left(\mathrm{NH}_{4}^{+}\right)$contents, as well as the $\mathrm{C} / \mathrm{N}, \mathrm{N} / \mathrm{S}$ and $\mathrm{Na}^{+} / \mathrm{K}^{+}$ratios were determined in the leaves of broccoli cultivars (Table 2). The $\mathrm{S}$ content was significantly
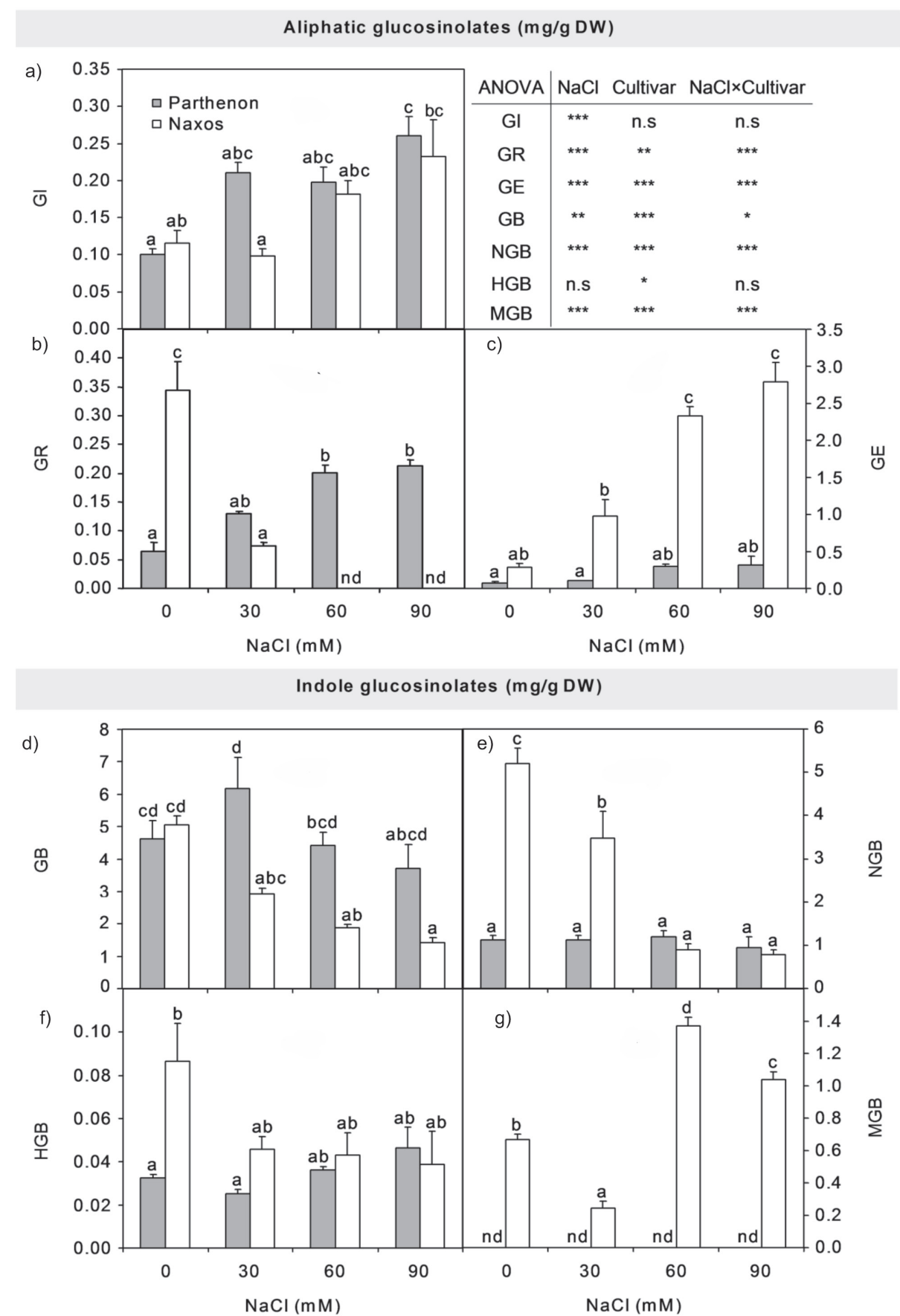

Fig. 1. Glucoiberin (GI) (A), glucoraphanin (GR) (B), glucoerucin (GE) (C), glucobrassicin (GB) (D), neoglucobrassicin (NGB) (E), 4-hydroxy-glucobrassicin (HGB) (F) and 4-methoxy-glucobrassicin (MGB) (G) contents in the leaves of broccoli plants grown for two weeks under saline conditions $(0,30,60$ or $90 \mathrm{mM} \mathrm{NaCl})$ differentiating between cultivars (cvs. Parthenon and Naxos). Bars are mean \pm standard error $(n=5)$. Mean values were calculated from five independent experiments. Means followed by a different lowercase letter are significantly different according to Tukey's test at $P<0.05$. Individual and combined effects of the two factors (salinity, cultivar) are given according to ANOVA tests, with significance expressed as follows: * at $P<0.05$; ** at $P<0.01 ; * * *$ at $P<0.001$. n.s: non significant. 
$(P<0.001)$ affected by individually studied factors ( $\mathrm{NaCl}$ treatment, cultivar), but not their interaction. Indeed, the same trend was presented by both $\mathrm{NaCl}$ treated cultivars compared with their respective controls: S content increased at 30 and $60 \mathrm{mM}$ then significantly decreased at $90 \mathrm{mM}$. Nevertheless, cv. Parthenon showed the highest values for $\mathrm{S}$ content at all $\mathrm{NaCl}$ levels. Moreover, a continuous significant decrease in $\mathrm{N}$ content was obtained in both cultivars with stress accentuation where the more significant reduction was noted in $\mathrm{cv}$. Naxos $(41.65 \%$ at $90 \mathrm{mM}$ $\mathrm{NaCl}$, referring to controls), which highlights the significant $(P<0.05)$ influences of cultivar factor and $\mathrm{NaCl} \times$ Cultivar interaction. Yet, despite the changes in the $\mathrm{S}$ and $\mathrm{N}$ contents under the different factors and their combination, the $\mathrm{N} / \mathrm{S}$ ratio was significantly affected only by $\mathrm{NaCl}$ treatment $(P<0.001)$. Thus, within each cultivar, all salt concentrations significantly reduced the N/S ratio with similar extent (almost 14\% and $28 \%$ in cvs. Parthenon and Naxos, respectively), as compared with the respective controls.

The $\mathrm{C}$ content was significantly $(P<0.001)$ influenced by the cultivar factor but not salinity or $\mathrm{NaCl} \times \mathrm{Cultivar}$ interaction, being the values lower in cv. Naxos than in cv. Parthenon under all treatments. A similar pattern of variation for $\mathrm{C} / \mathrm{N}$ ratio than that of $\mathrm{C}$ content was

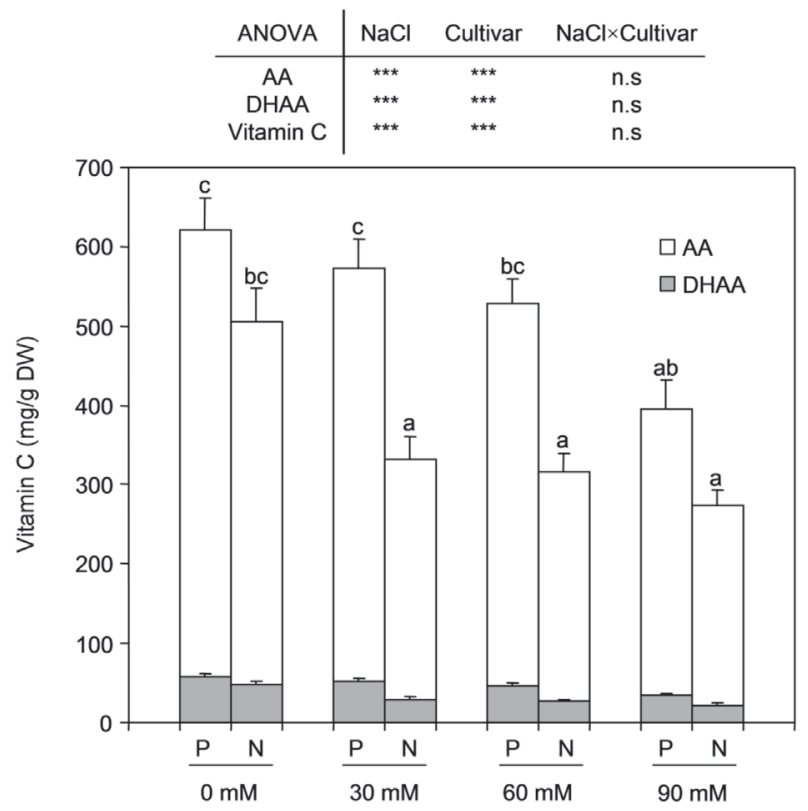

Fig. 2. Vitamin $\mathrm{C}$ content (the sum of ascorbic acid, AA, and dehydroascorbic acid, DHAA, levels) in the leaves of broccoli plants grown for two weeks under saline conditions $(0,30,60$ or $90 \mathrm{mM} \mathrm{NaCl}$ ) differentiating between cultivars (cvs. Parthenon and Naxos). Bars are mean \pm standard error $(n=5)$. Mean values were calculated from five independent experiments. Means followed by a different lower-case letter are significantly different according to Tukey's test at $P<0.05$. Individual and combined effects of the two factors (salinity, cultivar) are given according to ANOVA tests, with significance expressed as follows: * at $P<0.05$; ** at $P<0.01 ; * * *$ at $P<0.001$. n.s: non significant. observed following salinity treatment. Significant effects of salinity $(P<0.001)$ and cultivar $(P<0.01)$ factors, but not their interaction, on the leaf $\mathrm{NH}_{4}^{+}$content and $\mathrm{Na}^{+} / \mathrm{K}^{+}$ratio of the two broccoli cultivars were also recorded. $\mathrm{NH}_{4}^{+}$ions were significantly accumulated by $\mathrm{NaCl}$ stress from $60 \mathrm{mM}$ in cv. Parthenon and from $30 \mathrm{mM}$ in cv. Naxos. At $90 \mathrm{mM} \mathrm{NaCl}$, the $\mathrm{NH}_{4}^{+}$ content increment was about $61.26 \%$ and $63.10 \%$ in cvs Parthenon and Naxos, respectively, referring to controls. The $\mathrm{Na}^{+} / \mathrm{K}^{+}$ratio increased with increasing salinity in both cultivars, reaching 3.49 and $3.92 \mathrm{mmol} / \mathrm{Kg}$ DW in Parthenon and Naxos, respectively.

\section{Intact Glucosinolates}

The effects of salt treatment, cultivar factor and their combination on the individual GSLs analysed in the leaves of cvs. Parthenon and Naxos are shown in Fig. 1. In both cultivars under non-saline conditions, three aliphatics (glucoiberin, GI; glucoraphanin, GR; glucoerucin, GE) (Figs 1a-c) and four indolics (glucobrassicin, GB; neoglucobrassicin, NGB; 4-OHglucobrassicin HGB; 4-MeO-glucobrassicin, MGB (only in cv. Naxos)) (Figs 1d-g) were detected and quantified.

Among aliphatic GSLs, the GI content was solely influenced $(P<0.001)$ by $\mathrm{NaCl}$ treatment, being increased only at $90 \mathrm{mM}$ concentration (2.60- and

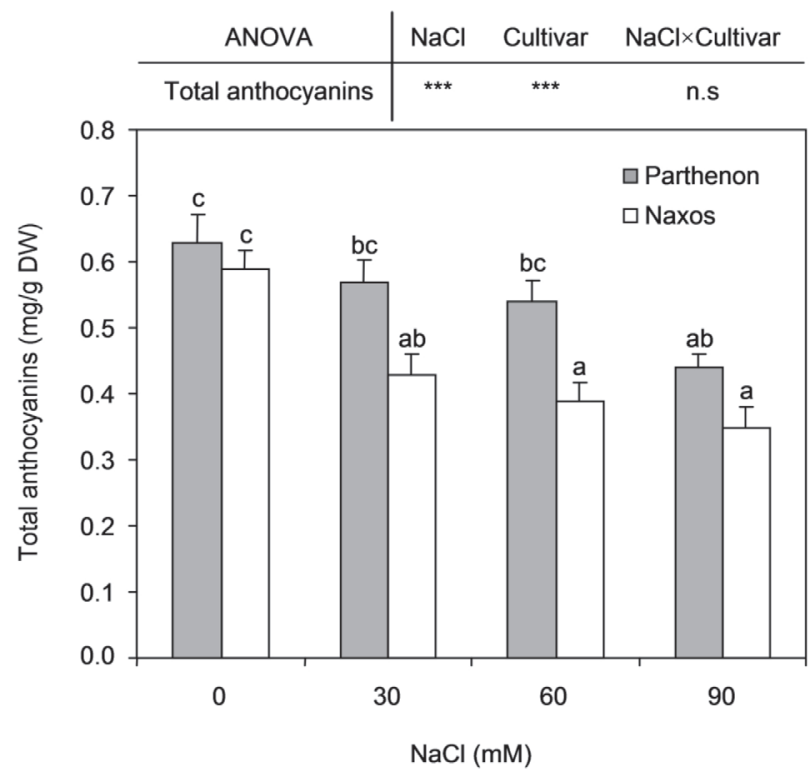

Fig. 3. Total anthocyanins content in the leaves of broccoli plants grown for two weeks under saline conditions $(0,30,60$ or 90 $\mathrm{mM} \mathrm{NaCl}$ ) differentiating between cultivars (cvs. Parthenon, $\mathrm{P}$, and Naxos, N). Bars are mean \pm standard error $(\mathrm{n}=5)$. Mean values were calculated from five independent experiments. Means followed by a different lower-case letter are significantly different according to Tukey's test at $P<0.05$. Individual and combined effects of the two factors (salinity, cultivar) are given according to ANOVA tests, with significance expressed as follows: * at $P<0.05 ; * *$ at $P<0.01 ; * * *$ at $P<0.001$. n.s: non significant. 
2.01-fold in cvs. Parthenon and Naxos, respectively, compared to controls) (Fig. 1a); whereas GR and GE were significantly affected $(P<0.001)$ by both studied factors and their interaction $(P<0.01$ for cultivar factor and GR). The GR content showed contradictor behaviour under salt stress, being significantly increased and decreased, respectively, in cvs. Parthenon and Naxos. At 60 and $90 \mathrm{mM} \mathrm{NaCl}$, the GR content was 3.32-fold the controls values in cv. Parthenon, whereas no levels were detected in cv. Naxos (Fig. 1b). The GE levels were influenced by salinity only in Naxos plants, being the values 9.6-fold higher than controls at $90 \mathrm{mM}$ $\mathrm{NaCl}$ (Fig. 1c).

Regarding indolic GSLs, both studied factors and their combination significantly $(P<0.001)$ influenced GB $(P<0.01$ for $\mathrm{NaCl}$ factor and $P<0.05$ for $\mathrm{NaCl} \times$ Cultivar interaction), NGB and MGB levels; however, HGB content was only affected by the cultivar factor $(P<0.05)$ (Fig. 1). Interestingly, compared to control plants, the levels of all detected indolic GSLs were not affected by salinity in cv. Parthenon, whereas they were significantly decreased in cv. Naxos (except for MGB concentration at 60 and $90 \mathrm{mM} \mathrm{NaCl}$ which was increased by 2.04- and 1.55-fold, respectively) (Figs 1d-g). At $90 \mathrm{mM} \mathrm{NaCl}$, the reduction in $\mathrm{GB}$ and NGB contents in leaves of Naxos plants reached $71.68 \%$ and $84.84 \%$, respectively, referring to controls.

\section{Total Vitamin C and Anthocyanins}

The AA and DHAA contents, separately or summed (total vitamin $\mathrm{C}$ content) (Fig. 2), as well as total anthocyanins (Fig. 3) showed significant $(P<0.001)$ variations in relation to individually applied salinity and cultivar factors, but not when combined. Comparing the cultivars, all applied $\mathrm{NaCl}$ treatments significantly reduced the total vitamin $\mathrm{C}$ and anthocyanins status in leaves of cv. Naxos (by $45.71 \%$ and $40.68 \%$, respectively, at $90 \mathrm{mM}$ ), whereas in Parthenon a reduction was observed only at highest concentration by about $36.27 \%$ and $30.16 \%$, respectively, referring to controls (Figs 2 and 3).

\section{Correlation Analysis of Phytochemicals with Micro- and Macroelements}

Table 3 provides Pearson's correlation coefficients and their associated $P$-values between levels of phytochemicals and mineral nutrient contents in leaves of Parthenon and Naxos plants. Regarding microelements, the marked significant correlations with the phytochemicals were observed for $\mathrm{Zn}^{2+}$ and $\mathrm{Mn}^{2+}$ ions contents. Thus, whereas in Parthenon a significant correlation for $\mathrm{Zn}^{2+}$ content was recorded only with GR and vitamin $\mathrm{C}(P<0.05)$, all bioactive compounds in Naxos leaves displayed strong relationship with this trace element, majorly negative. In contrast, $\mathrm{Mn}^{2+}$ levels were majorly correlated with aliphatic GSLs and anthocyanins in Parthenon plants.
In both cultivars, no significant correlations were observed for the studied phytochemicals with $\mathrm{S}$ and $\mathrm{C}$ contents, except for levels of $\mathrm{C}$ against GE $(P<0.05)$ and total anthocyanins $(P<0.01)$ in cv. Naxos. Also, only in the latter that significant correlations were found for $\mathrm{N}$ level against GI $(P<0.05)$, GR, GE, GB, NGB and vitamin $\mathrm{C}(P<0.01)$. Interestingly, $\mathrm{NH}_{4}^{+}$concentration showed negative correlation with the major indolics GB and NGB $(P<0.01)$ in Naxos leaves, while in Parthenon it was positively correlated with aliphatics GI and GR $(P<0.01)$. Vitamin $\mathrm{C}$ and anthocyanins were also negatively correlated with $\mathrm{NH}_{4}^{+}$content, independently to the plant cultivar. The N/S ratio showed similar correlation than that of $\mathrm{N}$ content with all individual GSLs (except for GI, where no significant correlation was found), vitamin $\mathrm{C}$ and total anthocyanins (positive correlation in both cultivars). In contrast, among all studied bioactive compounds, $\mathrm{C} / \mathrm{N}$ ratio was only significantly $(P<0.01)$ correlated with GI in cv. Parthenon.

\section{Discussion}

In this work, changes in leaf micro- and macroelement contents in response to salinity stress, cultivar factor and their interaction were investigated in broccoli (Brassica oleracea L. var. italica Plenck, cvs. Parthenon and Naxos) plants, as well as their correlations with individual GSLs, vitamin $\mathrm{C}$ and total anthocyanins composition. Here, as generally found in glycophytes [41, 42], the influence of the stress imposed by increasing salinity in the nutrient solution clearly increased leaf $\mathrm{Na}^{+} / \mathrm{K}^{+}$ratio in both cultivars from the lowest $\mathrm{NaCl}$ concentration $(30 \mathrm{mM})$, more pronounced in Naxos. Sodium chloride salt entered the plant and caused an interference with internal balance of solutes and the uptake of other nutrients [43, 44]. High cytosolic concentrations of $\mathrm{Na}^{+}$may disrupt $\mathrm{K}^{+}$homeostasis, which is often considered to be the primary cause of its toxicity under saline conditions [45]. The significant differences in $\mathrm{Zn}^{2+}, \mathrm{Mn}^{2+}$ and $\mathrm{B}^{3+}$ ions accumulation regarding both studied factors and their interaction clearly shows that though genes responsible for ion uptake are present in both cultivars, but their expression in cv. Naxos is much greater than in cv. Parthenon, as reported in salt-treated wheat cultivars by Hussain et al. [46]. Similarly, Lekshmy et al. [47] and Song et al. [48] observed a variation in the genotypes of plant in relation to their response and ability to metabolize micronutrient efficiently under saline conditions. In cv. Parthenon, the decreased $\mathrm{Mn}^{2+}$ content at high salinity could be due to damage to carriers, pumps or transporters of this micronutrient [49]. This decrease could also be partly due to the implication of $\mathrm{Mn}^{2+}$ ions in the activity of methylthioalkylmalate (MAM) synthases catalyzing the key enzymatic step in determining the length of the chain methioninederived GSLs, the condensation of acetyl-coenzyme 


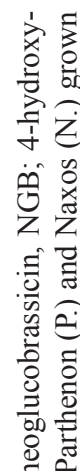

\begin{tabular}{|c|c|c|c|c|c|c|c|c|c|c|c|c|c|c|c|c|}
\hline \multirow{2}{*}{ 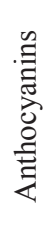 } & $z$ & तิ & $\begin{array}{l}\infty \\
\stackrel{\infty}{\infty} \\
\end{array}$ & 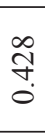 & 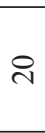 & $\begin{array}{l}\infty \\
\stackrel{\circ}{\circ} \\
\stackrel{0}{0}\end{array}$ & 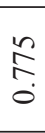 & $\gtrsim$ & 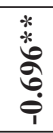 & $\overline{8}$ & ¿ి & $\begin{array}{l}\infty \\
\stackrel{\infty}{1}\end{array}$ & $\begin{array}{l}\text { fo } \\
\text { d }\end{array}$ & ¿ి & 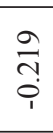 & 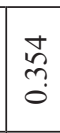 \\
\hline & D. & ¿ & $\begin{array}{l}\stackrel{n}{=} \\
\stackrel{0}{1}\end{array}$ & 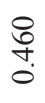 & 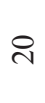 & 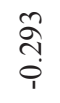 & $\begin{array}{l}\stackrel{\circ}{N} \\
\text { ○ }\end{array}$ & $\stackrel{\sim}{~}$ & $\begin{array}{l}\text { ò } \\
\text { ì }\end{array}$ & $\begin{array}{l}\stackrel{0}{0} \\
\stackrel{0}{0}\end{array}$ & ণ & 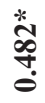 & है & 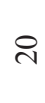 & $\begin{array}{l}+ \\
\text { ô } \\
0\end{array}$ & 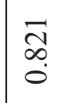 \\
\hline \multirow{2}{*}{ 点 } & $z$ & ণิ & $\begin{array}{l}\frac{i}{6} \\
0\end{array}$ & 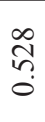 & নి & $\begin{array}{l}0 \\
\stackrel{0}{0} \\
\end{array}$ & 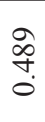 & $\gtrsim$ & $\begin{array}{l}\text { \% } \\
\text { to } \\
0 \\
0\end{array}$ & $\bar{\Xi}$ & 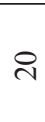 & $\begin{array}{l}\stackrel{\vec{N}}{\hat{i}} \\
\text { }\end{array}$ & 点 & ஜి & $\begin{array}{l}\stackrel{n}{0} \\
\dot{\varphi}\end{array}$ & $\begin{array}{l}8 \\
n \\
0\end{array}$ \\
\hline & si & సి & $\begin{array}{l} \pm \\
\text { - } \\
\\
\end{array}$ & 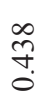 & 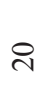 & $\begin{array}{l}\text { fे } \\
\text { m. } \\
\text { i }\end{array}$ & $\stackrel{m}{\stackrel{m}{0}}$ & $\stackrel{\sim}{ }$ & 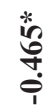 & ڤે & ‡े & ఫे & $\begin{array}{l}\tilde{n} \\
\stackrel{0}{0}\end{array}$ & ஜ & $\begin{array}{l}\overline{0} \\
\text { ! }\end{array}$ & $\begin{array}{l}\overrightarrow{6} \\
:\end{array}$ \\
\hline
\end{tabular}

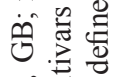

휘

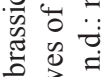

\begin{tabular}{|c|c|c|c|c|c|c|c|c|c|c|c|c|c|c|c|c|}
\hline \multirow[t]{2}{*}{ 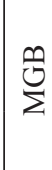 } & $\dot{z}$ & 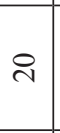 & $\begin{array}{l}\infty \\
\vdots \\
\stackrel{0}{i} \\
1\end{array}$ & $\begin{array}{l}\mathscr{0} \\
\stackrel{0}{0} \\
\stackrel{0}{0}\end{array}$ & 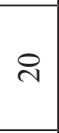 & ָิ & $\begin{array}{l}\overrightarrow{\tilde{\tau}} \\
0\end{array}$ & i & $\begin{array}{l}* \\
* \\
0 \\
\stackrel{0}{0} \\
\stackrel{0}{0}\end{array}$ & $\begin{array}{l}\dot{0} \\
\stackrel{0}{0} \\
0\end{array}$ & $\stackrel{\sim}{\text { i }}$ & $\frac{\hat{a}}{\grave{0}}$ & 号 & 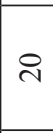 & $\underset{\forall}{\vec{F}}$ & 客 \\
\hline & ن & ¿ి & ت્ટ் & & iి & & & 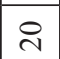 & ت্]త & & iి & ت્ગ & & i & ت̇ं & \\
\hline & $z$ & $\stackrel{\sim}{ }$ & $\stackrel{0}{\square}$ & $\stackrel{+}{+\infty}$ & ì & $\stackrel{q}{0}$ & $\begin{array}{l}\tilde{\omega} \\
\infty\end{array}$ & i & 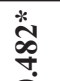 & $\overrightarrow{0}$ & ๙ิ & $\begin{array}{l}\infty \\
\substack{0 \\
0}\end{array}$ & $\stackrel{\varrho}{=}$ & i & $\underset{\sim}{\infty}$ & $\stackrel{m}{m}$ \\
\hline
\end{tabular}

on 0

뷩.

f

氖 总

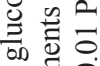

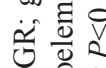

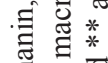

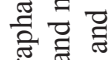

范

क力 .

论

或

ठี.

莺 豆

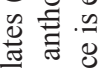

퓽 हू

疗

8

总

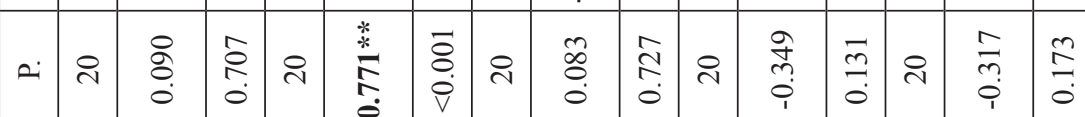

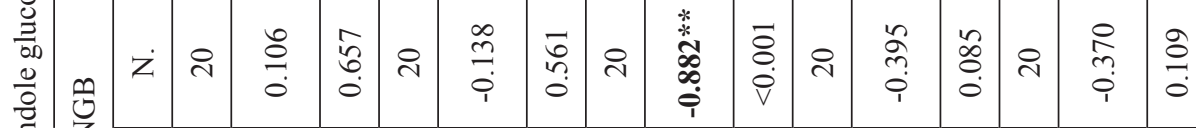

官

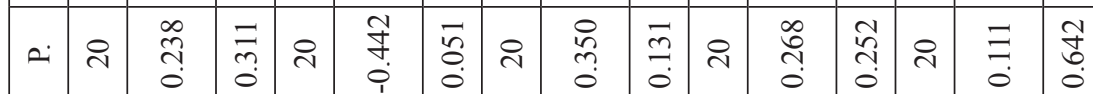

융

\begin{tabular}{|c|c|c|c|c|c|c|c|c|c|c|c|c|c|c|}
\hline$z$ & i & 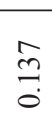 & $\begin{array}{l}\text { : } \\
: \\
0\end{array}$ & ¿ & $\stackrel{\text { ڤ. }}{0}$ & $\stackrel{\text { }}{\stackrel{2}{\circ}}$ & त & $\begin{array}{l}\text { * } \\
\stackrel{*}{\circ} \\
\stackrel{\alpha}{\circ}\end{array}$ & s. & त & $\begin{array}{l}\hat{\infty} \\
\text { ô } \\
0\end{array}$ & $\tilde{\delta}$ & ㅇ & 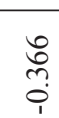 \\
\hline
\end{tabular}

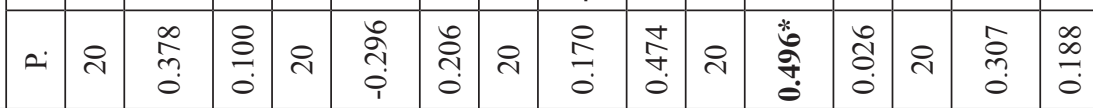

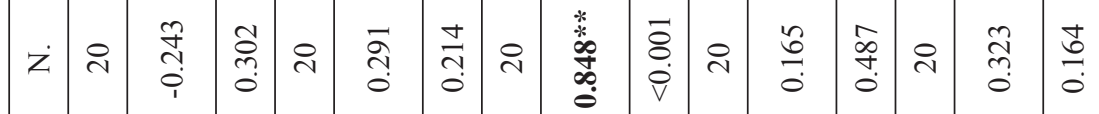

뜅

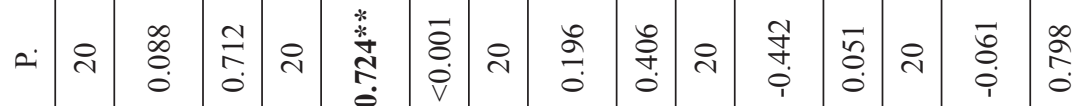

플

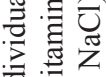

施

융요

可.

प.

苞

일

这

응 융

है

和

0 월

密.

ब.

ri

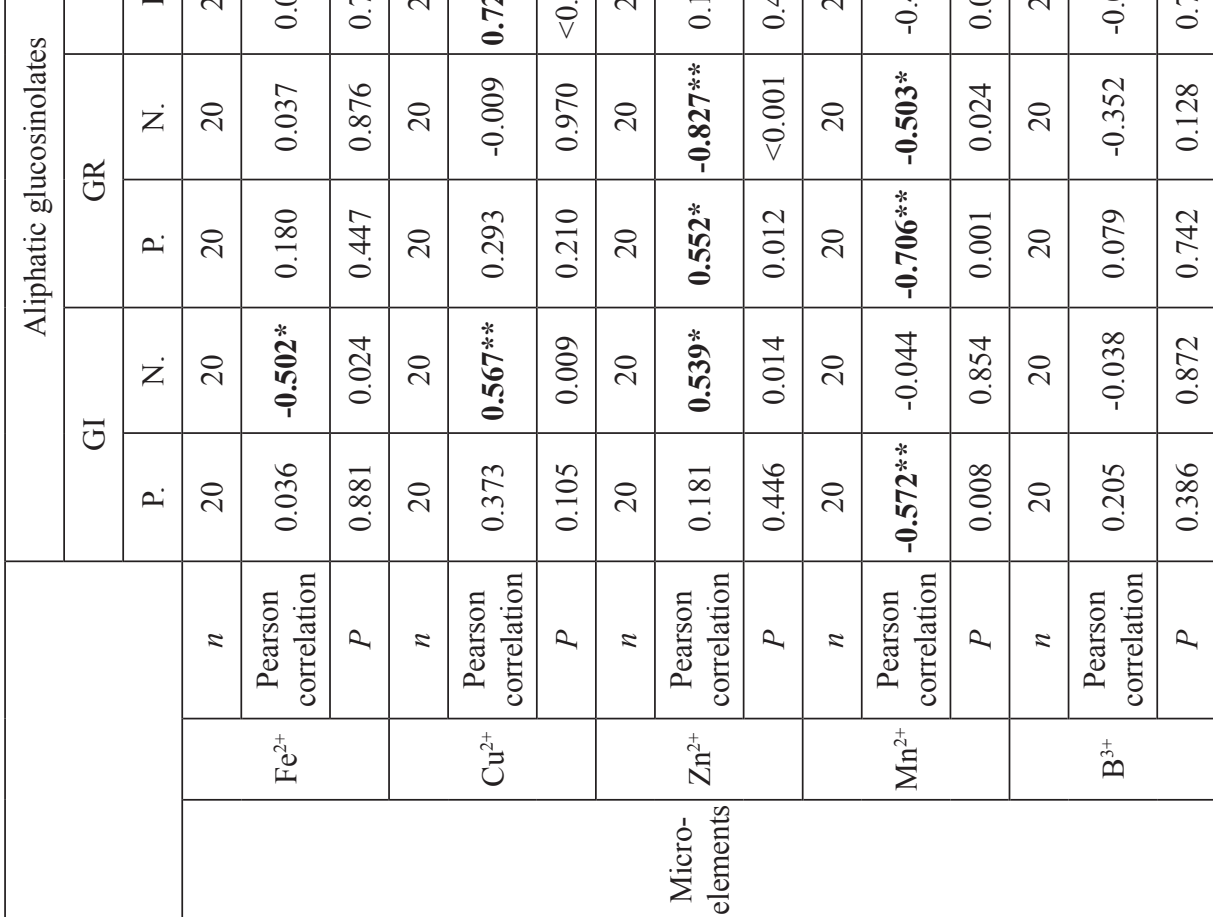




\begin{tabular}{|c|c|c|c|c|c|c|c|c|c|c|c|c|c|c|c|c|c|}
\hline$\sqrt{v}$ & 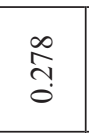 & ๙ิ & ㄱ. & 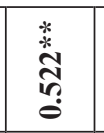 & $\begin{array}{l}\infty \\
0 \\
0 \\
0\end{array}$ & 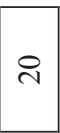 & 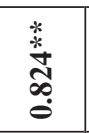 & $\begin{array}{l}\vec{\Xi} \\
\dot{v} \\
\vec{v}\end{array}$ & ¿ & 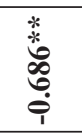 & $\begin{array}{l}\overrightarrow{8} \\
\dot{0}\end{array}$ & 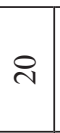 & $\begin{array}{l}\infty \\
\stackrel{\infty}{0} \\
\stackrel{0}{0}\end{array}$ & $\begin{array}{l}\vec{\nabla} \\
\dot{0}\end{array}$ & $\stackrel{\sim}{\sim}$ & 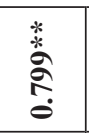 & $\begin{array}{l}\overline{8} \\
\dot{\circ} \\
\dot{v}\end{array}$ \\
\hline & $\stackrel{0}{\stackrel{0}{0}}$ & $\begin{array}{l}\infty \\
\stackrel{f}{f} \\
0\end{array}$ & ㄱ. & $\frac{+}{3}$ & 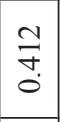 & $\stackrel{\text { i }}{\text { s. }}$ & $\begin{array}{l}* \\
\text { *. } \\
\text { c. } \\
\stackrel{0}{0}\end{array}$ & $\begin{array}{l}m \\
\tilde{\sigma}\end{array}$ & ¿ి & 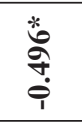 & $\begin{array}{l}\stackrel{0}{0} \\
\stackrel{\delta}{0}\end{array}$ & $\stackrel{\lambda}{ }$ & $\begin{array}{l}\overline{0} \\
\stackrel{1}{0} \\
i\end{array}$ & 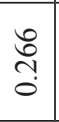 & ¿ & 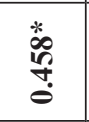 & $\begin{array}{l}\text { Iै } \\
\stackrel{0}{0}\end{array}$ \\
\hline & $\begin{array}{l}\text { I্t } \\
\text { ọ }\end{array}$ & $\begin{array}{l}\stackrel{\text { ते }}{0}\end{array}$ & ㄱ. & ڤે & $\begin{array}{l}2 \\
0 \\
0 \\
0\end{array}$ & 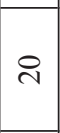 & 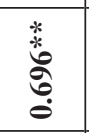 & $\begin{array}{l}\vec{\Xi} \\
\dot{0}\end{array}$ & ஜి & 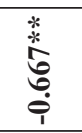 & $\begin{array}{l}\vec{\Xi} \\
\dot{0}\end{array}$ & 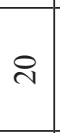 & $\begin{array}{l}\overrightarrow{\mathrm{a}} \\
\dot{\vec{v}}\end{array}$ & $\begin{array}{l}\stackrel{\partial}{\partial} \\
\text { ठे }\end{array}$ & $\stackrel{\sim}{\sim}$ & \begin{tabular}{l}
$*$ \\
\multirow{2}{*}{} \\
$\stackrel{0}{0}$ \\
$\stackrel{0}{0}$
\end{tabular} & 高 \\
\hline 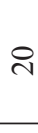 & $\begin{array}{l}\text { हे } \\
\text { రे }\end{array}$ & $\begin{array}{l}\stackrel{a}{0} \\
\stackrel{0}{0}\end{array}$ & ㄱ. & 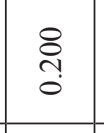 & $\hat{a}$ & ते & 菅 & $\begin{array}{l}\stackrel{\partial}{0} \\
\dot{0}\end{array}$ & 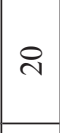 & 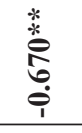 & $\begin{array}{l}\overrightarrow{8} \\
\dot{0}\end{array}$ & 요 & 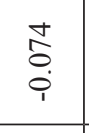 & $\begin{array}{l}0 \\
\stackrel{2}{0} \\
\vdots\end{array}$ & 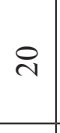 & $\stackrel{\infty}{0}$ & : \\
\hline 5 & 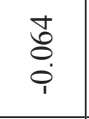 & $\begin{array}{l}\infty \\
\stackrel{\infty}{0} \\
0\end{array}$ & ㄱ. & $\begin{array}{l}\text { त̂̀ } \\
\text { }\end{array}$ & 年 & ते & 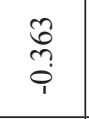 & $\begin{array}{l}\stackrel{n}{7} \\
0\end{array}$ & 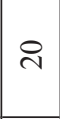 & \begin{tabular}{l} 
苂 \\
\multirow{0}{*}{} \\
0
\end{tabular} & 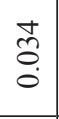 & ते & $\begin{array}{l}\overrightarrow{\widehat{O}} \\
\stackrel{i}{\dot{i}}\end{array}$ & $\vec{\sigma}$ & ¿ి & $\begin{array}{l}0 \\
\infty \\
\stackrel{0}{0} \\
\overbrace{1}\end{array}$ & $\begin{array}{l}\infty \\
\text { oे }\end{array}$ \\
\hline$\sqrt{4}$ & $\underset{\dot{I}}{\dot{J}}$ & & নి & $\underset{\dot{J}}{\dot{g}}$ & & ิ & $\stackrel{\vec{J}}{\dot{I}}$ & & ิ & $\stackrel{\dot{J}}{\dot{g}}$ & & ¿ิ & 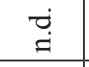 & & ิ & $\underset{\leftrightarrows}{\dot{I}}$ & \\
\hline & $\begin{array}{l}\stackrel{m}{0} \\
\stackrel{0}{i} \\
\end{array}$ & $\begin{array}{l}\tilde{n} \\
o \\
o\end{array}$ & ㄱ. & $\begin{array}{l}\overrightarrow{+} \\
\dot{Q} \\
\dot{i}\end{array}$ & $\begin{array}{l}n \\
0 \\
\infty \\
0 \\
0\end{array}$ & $\stackrel{\text { i }}{\text { s. }}$ & $\stackrel{+}{m}$ & $\stackrel{\infty}{\subseteq}$ & 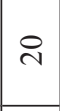 & $\begin{array}{l}\text { ָे } \\
\text { }\end{array}$ & $\begin{array}{l}\overrightarrow{\widetilde{\jmath}} \\
\text {. }\end{array}$ & 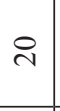 & $\begin{array}{l}\overrightarrow{\widehat{N}} \\
\stackrel{i}{i}\end{array}$ & ڤેे & $\stackrel{\sim}{\sim}$ & $\begin{array}{l}+ \\
\stackrel{\infty}{0} \\
0\end{array}$ & 吕 \\
\hline & $\begin{array}{l}0 \\
0 \\
0 \\
0 \\
1\end{array}$ & $\begin{array}{l}0 \\
\infty \\
\infty \\
0 \\
0\end{array}$ & 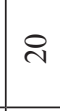 & $\begin{array}{l}0 \\
\stackrel{0}{0} \\
\stackrel{0}{0}\end{array}$ & 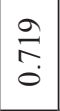 & 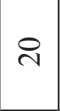 & $\frac{8}{9}$ & $\begin{array}{l}\overrightarrow{\mathcal{Y}} \\
\stackrel{\circ}{\circ}\end{array}$ & ¿ & $\stackrel{m}{=}$ & $\begin{array}{l}n \\
0 \\
0 \\
0 \\
0\end{array}$ & 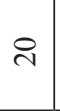 & ڤ్) & $\begin{array}{l}\vec{\infty} \\
\tilde{0} \\
\tilde{0}\end{array}$ & 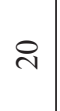 & $\frac{\vec{n}}{0}$ & \begin{tabular}{l}
\multirow{J}{N}{} \\
$\stackrel{2}{0}$
\end{tabular} \\
\hline 8 & $\begin{array}{l}\text { तิ } \\
\text { ஸे }\end{array}$ & $\begin{array}{l}\vec{n} \\
\stackrel{?}{0}\end{array}$ & ㄱ. & స్ & $\stackrel{n}{n}$ & 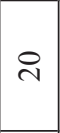 & \begin{tabular}{l}
$*$ \\
\multirow{2}{*}{} \\
$\stackrel{\circ}{\circ}$ \\
$\stackrel{0}{0}$
\end{tabular} & $\begin{array}{l}\vec{\Xi} \\
\dot{\vec{v}}\end{array}$ & ¿ి & \begin{tabular}{l}
$*$ \\
\multirow{2}{*}{} \\
$\stackrel{0}{0}$ \\
$\stackrel{0}{0}$ \\
$\dot{0}$
\end{tabular} & $\begin{array}{l}\vec{\Xi} \\
\dot{0}\end{array}$ & શે & 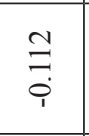 & $\begin{array}{l}\hat{0} \\
\dot{6} \\
0\end{array}$ & 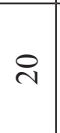 & $\frac{*}{\stackrel{*}{*}}$ & $\begin{array}{l}\overline{8} \\
\dot{0}\end{array}$ \\
\hline & $\begin{array}{l}\text { वे } \\
\stackrel{0}{0} \\
\end{array}$ & $\begin{array}{l}\infty \\
\infty \\
\infty \\
0 \\
0\end{array}$ & ๙ & 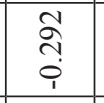 & $\begin{array}{c}\overrightarrow{\vec{\sim}} \\
\tilde{0}\end{array}$ & ते & $\begin{array}{l}n \\
\hat{o} \\
0 \\
i\end{array}$ & $\begin{array}{l}\infty \\
\infty \\
0 \\
0\end{array}$ & 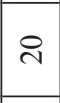 & $\begin{array}{l}0 \\
\stackrel{1}{1} \\
\end{array}$ & \begin{tabular}{l}
$\infty$ \\
\multirow{2}{p}{} \\
0 \\
0
\end{tabular} & 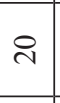 & $\begin{array}{l}n \\
\tilde{n} \\
i \\
i\end{array}$ & \begin{tabular}{l}
$\infty$ \\
\multirow{2}{*}{} \\
0
\end{tabular} & $\stackrel{\sim}{~}$ & $\begin{array}{l}\overline{\mathrm{a}} \\
\dot{i}\end{array}$ & $\begin{array}{l}\stackrel{+}{0} \\
0\end{array}$ \\
\hline$\sqrt{v}$ & 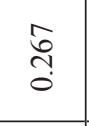 & $\begin{array}{l}\text { ñ } \\
\text { å }\end{array}$ & ㄱ. & $\begin{array}{l}8 \\
\text { ?. } \\
0\end{array}$ & $\frac{\partial}{\partial}$ & $\stackrel{\text { i }}{\text { s. }}$ & 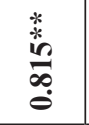 & $\begin{array}{l}\overrightarrow{8} \\
\dot{0} \\
\dot{v}\end{array}$ & ¿ & 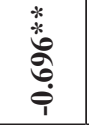 & $\begin{array}{l}\overrightarrow{8} \\
\dot{0}\end{array}$ & ‡ి & $\frac{\tilde{\infty}}{\stackrel{0}{i}}$ & $\stackrel{\stackrel{\vartheta}{f}}{\stackrel{0}{0}}$ & 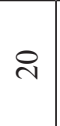 & $\frac{*}{*}$ & $\begin{array}{l}\overline{8} \\
\dot{\mathrm{v}}\end{array}$ \\
\hline & $\stackrel{\vec{n}}{0}$ & त̂ & ๙ి & 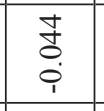 & $\begin{array}{l}n \\
\infty \\
0 \\
0\end{array}$ & ते & $\begin{array}{l}\text { o } \\
\vdots \\
0 \\
1\end{array}$ & 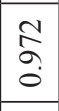 & ¿ & 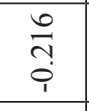 & $\begin{array}{l}\text { के } \\
\tilde{c} \\
0\end{array}$ & ㅇ & $\begin{array}{l}0 \\
0 \\
0 \\
i\end{array}$ & 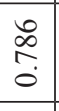 & 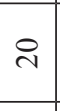 & 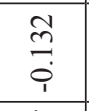 & $\begin{array}{l}\infty \\
\text { in } \\
0\end{array}$ \\
\hline 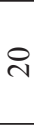 & 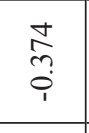 & $\frac{n}{\stackrel{0}{0}}$ & ㄱ. & 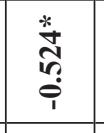 & $\begin{array}{l}\infty \\
\stackrel{\infty}{0} \\
0\end{array}$ & ते & $\begin{array}{l}\text { * } \\
\stackrel{*}{\infty} \\
\stackrel{\infty}{0} \\
\stackrel{i}{i}\end{array}$ & $\begin{array}{l}\vec{\Xi} \\
\dot{\vec{v}}\end{array}$ & ¿े & $\frac{*}{*}$ & $\begin{array}{l}\vec{\Xi} \\
\dot{\vec{v}}\end{array}$ & ஜి & $\frac{\hat{0}}{0}$ & 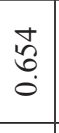 & 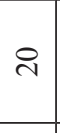 & 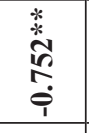 & $\begin{array}{l}\vec{\delta} \\
\dot{\hat{\theta}} \\
\mathrm{v}\end{array}$ \\
\hline & $\frac{2}{0}$ & $\stackrel{\infty}{\underset{0}{*}}$ & ㄱ. & $\begin{array}{l}\infty \\
\stackrel{0}{0} \\
\stackrel{0}{0}\end{array}$ & 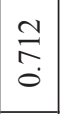 & ते & $\frac{0}{m}$ & $\stackrel{n}{=}$ & 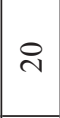 & 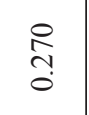 & 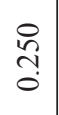 & ஜิ & $\begin{array}{l}n \\
\text { n? } \\
0\end{array}$ & $\begin{array}{l} \pm \\
\stackrel{+}{0}\end{array}$ & 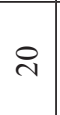 & $\underset{i}{\vec{j}}$ & 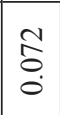 \\
\hline & $\stackrel{\text { ले }}{0}$ & $\begin{array}{l}8 \\
\stackrel{0}{0} \\
0\end{array}$ & ㄱ. & $\frac{n}{\grave{0}}$ & $\underset{\vec{J}}{\vec{J}}$ & 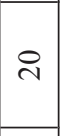 & \begin{tabular}{l}
$*$ \\
$*$ \\
\multirow{0}{*}{} \\
$\stackrel{0}{0}$ \\
0
\end{tabular} & $\begin{array}{l}\vec{\circ} \\
\dot{0}\end{array}$ & ஜి & 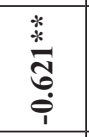 & $\begin{array}{l} \pm \\
\stackrel{0}{0} \\
\dot{0}\end{array}$ & 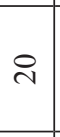 & 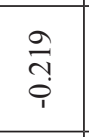 & $\begin{array}{c}\tilde{n} \\
\tilde{c} \\
0\end{array}$ & 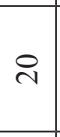 & 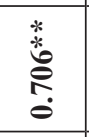 & $\bar{\square}$ \\
\hline & $\frac{n}{i}$ & ते & ‡) & o̊ & $\begin{array}{l}0 \\
\text { à } \\
0\end{array}$ & ते & $\begin{array}{l}\stackrel{7}{~} \\
\stackrel{+}{i}\end{array}$ & $\begin{array}{l}\vec{\Xi} \\
\stackrel{0}{0}\end{array}$ & 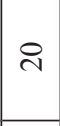 & 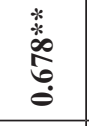 & $\begin{array}{l}\overrightarrow{8} \\
\dot{0}\end{array}$ & શે & $\stackrel{\bar{m}}{\tilde{0}}$ & $\begin{array}{l}0 \\
\stackrel{\infty}{0}\end{array}$ & 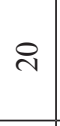 & $\begin{array}{l}\text { ते } \\
\text { ì }\end{array}$ & $\underset{\widetilde{I}}{\stackrel{I}{0}}$ \\
\hline & 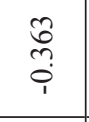 & $\begin{array}{l}0 \\
= \\
0\end{array}$ & ㄱ. & $\begin{array}{l}0 \\
\infty \\
\infty \\
0 \\
1\end{array}$ & $\stackrel{m}{o}$ & ते & 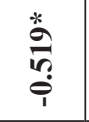 & $\stackrel{a}{\partial}$ & 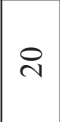 & 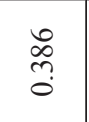 & $\stackrel{\text { ô }}{0}$ & $\stackrel{\sim}{2}$ & $\stackrel{\text { ले }}{\stackrel{i}{i}}$ & $\begin{array}{l}\infty \\
n \\
n \\
0\end{array}$ & ¿ & $\begin{array}{l}\hat{o} \\
\stackrel{q}{i} \\
\text { in }\end{array}$ & $\begin{array}{l}n \\
0 \\
0\end{array}$ \\
\hline & 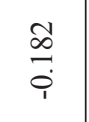 & 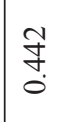 & ণे & 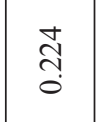 & 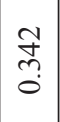 & ते & \begin{tabular}{l}
0 \\
\multirow{2}{*}{} \\
$\stackrel{0}{i}$
\end{tabular} & $\begin{array}{l}n \\
0 \\
0\end{array}$ & 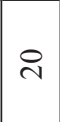 & $\stackrel{*}{\stackrel{*}{*}}$ & $\begin{array}{l}\infty \\
0 \\
0 \\
0\end{array}$ & 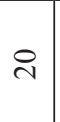 & $\begin{array}{l}* \\
\stackrel{*}{*} \\
\stackrel{c}{n g} \\
0\end{array}$ & $\begin{array}{l}\infty \\
\stackrel{0}{0} \\
0\end{array}$ & নे & $\begin{array}{l}\stackrel{0}{ } \\
\text { ָ̦ }\end{array}$ & 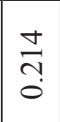 \\
\hline & 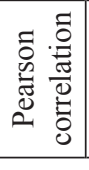 & 2 & $=$ & 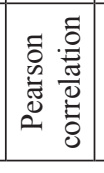 & 2 & $=$ & 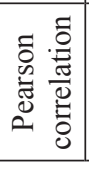 & 2 & $=$ & 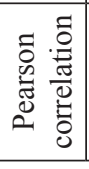 & 2 & $=$ & 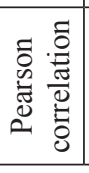 & 2 & $=$ & 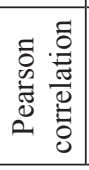 & 2 \\
\hline & is & & & $u$ & & & $z$ & & & ${\stackrel{\mathbf{Z}^{+}}{+}}^{+}$ & & & Z & & & $\frac{\pi}{z}$ & \\
\hline
\end{tabular}


A with a series of $\omega$-methylthio-2-oxoalkanoic acids [50], which explain the observed strong negative correlation between this mineral and increased individual aliphatics in Parthenon. The uptake and accumulation of ions in plants is considered as an important indicator of salinity tolerance, because they are genetically regulated, though also affected by the environment [51, 52]. However, in this study, $\mathrm{Cu}^{2+}$, $\mathrm{Zn}^{2+}$ and $\mathrm{Mn}^{2+}$ ions accumulation under salinity was the highest in cv. Naxos, mainly at moderate salinity $(60 \mathrm{mM} \mathrm{NaCl})$, despite its greater biomass reduction without deficiency symptoms, compared to Parthenon [53]. It seems that, when reduced growth imposed by salinity became important, nutrient supply in leaves was adequate to support growth, as observed in tomato by Nouck et al. [54].

Also, the significant influence of individually applied salinity and cultivar factor on $\mathrm{S}$ contents in our broccoli leaves - being the values reduced only in cv. Naxos at high salinity $(90 \mathrm{mM} \mathrm{NaCl})-$ was probably due to the incorporation of this mineral into S-containing metabolites [55]. However, as no correlation was observed between endogenous levels of this mineral nutrient and any of individual GSLs in both broccoli cultivars, the reduced $\mathrm{S}$ levels in cv. Naxos could be caused by $\mathrm{S}$ participation in the synthesis of antioxidant molecules - such as ascorbate and glutathione - acting as cell redox regulator and as a reactive oxygen species (ROS) scavenger under salt stress, as observed by Rodríguez-Hernández et al. [56] with the same broccoli cultivar. Indeed, salinity induces the formation of ROS within plant cells, and its over accumulation results in oxidative damage of membrane lipids, proteins and nucleic acids [57, 58]. In contrast, in this work, the differential response of both broccoli cultivars regarding the salinity effects on endogenous leaf $\mathrm{N}$ results distinctive patterns for their GSLs composition, with a significant correlation observed only in cv. Naxos. In accordance with our results, He et al. [59] and Marino et al. [60] reported that GSLs synthesis was mainly affected by the tissue endogenous $\mathrm{N}$, as an essential constituent of the GSLs amino acids precursors. However, GSLs composition in the different plant parts actually depends on both $\mathrm{N}$ and $\mathrm{S}$ levels, rather than their individual concentrations [61]. Therefore, the lack of correlation between total $\mathrm{N}$ and GSLs in Parthenon was probably due to the stable $\mathrm{N} / \mathrm{S}$ ratio in this cultivar. In Naxos, this ratio showed a similar reduction tendency than that of $\mathrm{N}$ content from $30 \mathrm{mM} \mathrm{NaCl}$ concentration - because of the predominant effect of salt stress, as it was unaffected by the cultivar factor alone or in combination with salinity. The more the N/S ratio decreases because of diminished $\mathrm{N}$ content, the stronger the synthesis of sulfurous cysteine as a precursor of methionine seems to be [62]. Moreover, cysteine and methionine act as effective sulfur donors in thiohydroximate formation in the synthesis of aliphatic and indole GSLs [63, 64]. However, in this work, GR in Naxos leaves was the only minor aliphatic GSL that decreased by increasing salinity, whereas of the indole GSLs, GB and NGB were reduced with decreased $\mathrm{N}$ content and $\mathrm{N} / \mathrm{S}$ ratio, confirming that indole GSLs usually are more affected by environmental stress $[65,66]$. We assume that, in cv. Naxos, the synthesis of tryptophan-derived indole GSLs is not so strongly sulfur-dependent as the synthesis of methionine-derived aliphatic GSLs, thereby explaining the positive correlation between individual major indole GSLs content (GB and $\mathrm{NGB}$ ) and $\mathrm{N} / \mathrm{S}$ ratio and $\mathrm{N}$ content, respectively. The decreases in individual indole GSLs contents in Naxos under salinity could be attributed to the break down of GSLs (hydrolysis) due to cellular damage caused by oxidative stress, as observed by Sarikamiş and Çakir [67]. In addition, the majorly negative significant correlations between $\mathrm{Zn}^{2+}$ ions and indole GSLs observed mainly in cv. Naxos confirmed the results of Tolrà et al. [68] in Thlaspi caerulescens shoots, and may result from $\mathrm{Zn}$-induced changes in sulfur pools and/or responses related to defence, as high $\mathrm{Zn}$ concentrations have been shown to inhibit sulfation of desulfo-GSLs [69, 70]. In contrast, increased levels of GI and GE, as aliphatic GSLs, was probably to compensate the decline in indolics. In fact, indole GSLs were increased in the Arabidopsis thaliana (L.) Heynh. double mutant myb28myb29 completely lacking aliphatic GSLs [71]. In Parthenon, the NaClinduced increment in GI and GR aliphatics, and the no changes in individual indolics confer to this cultivar a greater nutritional value when cultivated under saline conditions. Indeed, the hydrolysis product of GR, sulforaphane (an isothiocyanate), possesses the capacity to reduce the risk of cancers through the cell cycle blockage and apoptosis activation [72]. In both broccoli cultivars, the observed increase in individual aliphatic GSLs may have a role in osmotic adjustment and might be an adaptive component of salt tolerance, as reported by Martínez-Ballesta et al. [73]. Moreover, the lack of correlation between the $\mathrm{C} / \mathrm{N}$ ratio and individual indolic and aliphatic (except for GI in Parthenon) GSLs in both cultivars indicates that the $\mathrm{C} / \mathrm{N}$ relationship could not be a bioindicator of the changes in GSLs seen under Salinity $\times$ Cultivar interaction. Therefore, GSLs composition in cultivars Parthenon and Naxos depends on the genetic and environmental factors and their interaction that influenced endogenous nutrients; Naxos, ideal for semi arid regions, being more sensitive to salinity.

In both cultivars, the total vitamin $\mathrm{C}$ content was differently reduced by salinity in a stress intensitydependent manner, but was unaffected when studied factors where combined. Interestingly, in both cultivars, an opposite pattern of variation than that of vitamin $\mathrm{C}$ was recorded for $\mathrm{NH}_{4}^{+}$content, resulting significant negative correlations. It has been reported that $\mathrm{NH}_{4}^{+}-$ accumulating plants operate metabolic pathways that generate more oxygen radicals $[74,75]$. Thus, the higher reduction in vitamin $\mathrm{C}$ in $\mathrm{cv}$. Naxos compared 
to Parthenon under salinity seems to be the result of AA participation in the reduction of $\mathrm{H}_{2} \mathrm{O}_{2}$, through the increased ascorbate peroxidase activity [28, 29]. Indeed, in salt-sensitive species, the AA content could decrease due to salinity stress [26, 27], as result of the drop in the level of its metabolic intermediate GDP-mannose [76]. Moreover, only in cv. Naxos that changes in vitamin $\mathrm{C}$ levels were highly correlated with endogenous $\mathrm{N}$ contents. Our results are in agreement with those obtained by Kováčik et al. [77] in barley plants (Hordeum vulgare L. cv. Bojos), where decreasing endogenous $\mathrm{N}$ contents reduces the amount of AA in the shoots due to enhanced symptoms of oxidative stress. Vitamin $\mathrm{C}$ was also inversely related to endogenous $\mathrm{Zn}^{2+}$ ions in both cultivars, probably as result of the catalytic action of these ions on ascorbate oxidation [78]. Therefore, the influence of the genetic background - as observed for individual GSLs - on the vitamin $\mathrm{C}$ concentration due to $\mathrm{NaCl}$ application highlights not only the importance of the biological factor (cultivar) but also the influence of environmental stress.

The total anthocyanin content showed a closely similar response to both studied factors and their combination than that of vitamin $C$, suggesting the main role of these two compounds in the antioxidant capacity of broccoli leaves under salinity. A reduction in the total anthocyanin content in response to salt stress was also reported by Chunthaburee et al. [79] in rice seedlings, and was attributed to the down-regulation of late biosynthetic genes dihydroflavonol-4-reductase (DFR) and anthocyanidin synthase (ANS). Anthocyanins are plant secondary metabolites synthesized by flavonoid biosynthesis pathway using phenylalanine as precursor [80]; the latter is a derivative of alanine with a phenyl substituent on the $\beta$ carbon. Previously [39], we have reported significant reduction in the leaf alanine content of cv. Parthenon under $80 \mathrm{mM}$ $\mathrm{NaCl}$ treatment, which could explain at least in part the decrease in total anthocyanins observed in this work. In both cultivars, as for vitamin $\mathrm{C}$, the total concentration of anthocyanins was significantly inversely correlated with the $\mathrm{NH}_{4}^{+}$content. Anthocyanins are very effective donors of hydrogen to highly reactive free radicals (such as superoxide $\left(\mathrm{O}_{2}^{-}\right)$, singlet oxygen $\left({ }^{1} \mathrm{O}_{2}\right)$, peroxide $(\mathrm{RCOO} \cdot)$, hydrogen peroxide $\left(\mathrm{H}_{2} \mathrm{O}_{2}\right)$, hydroxyl radical $(\mathrm{OH} \cdot)$ and reactive nitrogen species in a terminator reaction), thereby preventing further radical formation and protecting cells from oxidative damage [24, 25]. Interestingly, only in cv. Naxos that a strong negative correlation was observed between contents of $\mathrm{Zn}^{2+}$ ions and total anthocyanins, confirming the results of Zhang et al. [81] and Sai Kachout et al. [82] where excessive accumulation of trace metals limit anthocyanin biosynthesis by inhibiting activity of 1-phenylalanine ammonia-lyase (PAL). These findings explain the anthocyanin reduction in cv. Naxos from the lowest $\mathrm{NaCl}$ concentration $(30 \mathrm{mM})$, compared to Parthenon.

\section{Conclusion}

Significant differences in micro- $\left(\mathrm{Fe}^{2+}, \mathrm{Cu}^{2+}\right.$, $\mathrm{Zn}^{2+}, \mathrm{Mn}^{2+}$ and $\mathrm{B}^{3+}$ ) and macroelements ( $\mathrm{S}, \mathrm{N}, \mathrm{C}$, $\mathrm{NH}_{4}^{+}$) contents regarding the studied factors and/ or their interaction were recorded in broccoli leaves. In Parthenon, salinity significantly increased leaf glucoiberin (GI) and glucoraphanin (GR), being the values correlated with $\mathrm{Mn}^{2+}$ ions $(P<0.01)$, without affecting any of detected individual indolics. However, in Naxos, GR was decreased as well as the major indole GSLs, being the correlations $(P<0.01)$ positive with $\mathrm{N}$ and $\mathrm{N} / \mathrm{S}$ ratio and negative with $\mathrm{NH}_{4}^{+}$content. In addition, whereas in Parthenon a significant correlation for $\mathrm{Zn}^{2+}$ content was recorded only with GR and vitamin $\mathrm{C}(P<0.05)$, all bioactive compounds in Naxos leaves displayed strong relationship with this mineral nutrient, majorly negative. The levels of vitamin $\mathrm{C}$ and total anthocyanins were more stable under salinity in cv. Parthenon (until $60 \mathrm{mM} \mathrm{NaCl}$ ) than in Naxos (decreased from $30 \mathrm{mM} \mathrm{NaCl}$ ), with an opposite pattern of variation than $\mathrm{NH}_{4}^{+}$ions. In the light of these results, genotypic variation in the phytochemical load of GSLs, vitamin $\mathrm{C}$ and total anthocyanins in broccoli leaves under salinity were induced by changes in their mineral composition.

\section{Acknowledgements}

The authors thank Prof. Asma Ben Jbara, for the correction of the written English in the manuscript. The authors are very grateful to the Aquaporins Group (Dep. of Plant Nutrition) and Phytochemistry Lab. (Dept. of Food Science and Technology) from the Centro de Edafología y Biología Aplicada del Segura (CEBAS-CSIC) for the HPLC/MS analyses, and SAKATA IBERICA, for providing the seeds. This work was supported by the Tunisian Ministry of Higher Education, Scientific Research and Technology (LR11IRA02).

\section{Conflict of Interest}

The authors declare no conflict of interest.

\section{References}

1. MUNNS R., GILLIHAM M. Salinity tolerance of crops what is the cost? New Phytol. 208, 668, 2015.

2. YANG Y., GUO Y. Elucidating the molecular mechanisms mediating plant salt-stress responses. New Phytol. 217, 523, 2018.

3. MONTOROI J.-P. Soil salinization and management of salty soils. In: Soils as a key component of the critical zone 5: Degradation and rehabilitation. ISTE Ltd, London, UK; John Wiley \& Sons, Inc., Hoboken, NJ, USA, ISBN: 978-1786-30219-9, 97, 2018. 
4. PARIHAR P., SINGH S., SINGH R., SINGH V.P., PRASAD S.M. Effect of salinity stress on plants and its tolerance strategies: a review. Environ. Sci. Pollut. Res. 22 (6), 4056, 2015.

5. CRUZ J.L., COELHO E.F., COELHO FILHO M.A., dos SANTOS A.A. Salinity reduces nutrients absorption and efficiency of their utilization in cassava plants. Cienc. Rural 48 (11), e20180351, 2018.

6. MACHADO R.M.A., SERRALHEIRO R.P. Soil salinity: Effect on vegetable crop growth. Management practices to prevent and mitigate soil salinization. Horticulturae 3, 30, 2017.

7. GARCÍA-CAPARRÓS P., HASANUZZAMAN M., LAO M.T. Oxidative stress and antioxidant defense in plants under salinity. In: Reactive oxygen, nitrogen and sulfur species in plants: Production, metabolism, signaling and defense mechanisms. First edition. John Wiley \& Sons Ltd, Hoboken, NJ, USA, ISBN: 978-1-119-46864-6, 1, 291, 2019.

8. HU Y., SCHMIDHALTER U. Effects of salinity and macronutrient levels on micronutrients in wheat. J. Plant Nutr. 24 (2), 273, 2001.

9. TURHAN E., ERIS A. Changes of micronutrients, dry weight, and chlorophyll contents in strawberry plants under salt stress conditions. Commun. Soil Sci. Plant Anal. 36 (7-8), 1021, 2005

10. CHRYSARGYRIS A., MICHAILIDI E., TZORTZAKIS N. Physiological and biochemical responses of Lavandula angustifolia to salinity under mineral foliar application. Front. Plant Sci. 9, 489, 2018.

11. CHAKRABORTY K., SAIRAM R.K., BHADURI D. Effects of different levels of soil salinity on yield attributes, accumulation of nitrogen, and micronutrients in Brassica spp. J. Plant Nutr. 39 (7), 1026, 2015.

12. GÓMEZ BELLOT M.J., CARMASSI G., BARTALUCCI M., SÁNCHEZ-BLANCO M.J., PARDOSSI A. Growth, evapotranspiration and mineral content of gerbera under combined salinity and excess boron. J. Hortic. Res. 26 (2), 61, 2018.

13. ANJUM S.A., ASHRAF U., TANVEER M., KHAN I., HUSSAIN S., SHAHZAD B., ZOHAIB A., ABBAS F., SALEEM M.F., ALI I., WANG L.C. Drought induced changes in growth, osmolyte accumulation and antioxidant metabolism of three maize hybrids. Front. Plant Sci. 8, 69, 2017.

14. ULLAH A., LI M., NOOR J., TARIQ A., LIU Y., SHI L. Effects of salinity on photosynthetic traits, ion homeostasis and nitrogen metabolism in wild and cultivated soybean. PeerJ 7, e8191, 2019.

15. LIU L., WANG B., LIU D., ZOU C., WU P., WANG Z., WANG Y., LI C. Transcriptomic and metabolomic analyses reveal mechanisms of adaptation to salinity in which carbon and nitrogen metabolism is altered in sugar beet roots. BMC Plant Biol. 20, 138, 2020.

16. KHAN N.A., KHAN M.I.R., ASGHER M., FATMA M., MASOOD A., SYEED S. Salinity tolerance in plants: revisiting the role of sulfur metabolites. J. Plant Biochem. Physiol. 2 (1), 1, 2014.

17. HÄNSCH R., MENDEL R.R. Physiological functions of mineral micronutrients $(\mathrm{Cu}, \mathrm{Zn}, \mathrm{Mn}, \mathrm{Fe}, \mathrm{Ni}, \mathrm{Mo}, \mathrm{B}, \mathrm{Cl})$. Curr. Opin. Plant Biol. 12 (3), 259, 2009.

18. SYTAR O., MBARKI S., ZIVCAK M., BRESTIC M. The involvement of different secondary metabolites in salinity tolerance of crops. In: Salinity responses and tolerance in plants. Chapter 2. Springer International Publishing AG, part of Springer Nature, Berlin, 2018.
19. SOUNDARARAJAN P., KIM J.S. Anti-carcinogenic glucosinolates in cruciferous vegetables and their antagonistic effects on prevention of cancers. Molecules $\mathbf{2 3}$ (11), 2983, 2018.

20. MELROSE J. The glucosinolates: a sulphur glucoside family of mustard anti-tumour and antimicrobial phytochemicals of potential therapeutic application. Biomedicines 7 (3), 62, 2019.

21. RIOS J.J., AGUDELO A., MORENO D.A., CARVAJAL M. Growing broccoli under salinity: the influence of cultivar and season on glucosinolates content. Sci. Agric. 77 (6), e20190028, 2020

22. AGAMI R.A. Applications of ascorbic acid or proline increase resistance to salt stress in barley seedlings. Biol. Plant. 58, 341, 2014.

23. CHUNTHABUREE S., SAKUANRUNGSIRIKUL S., WONGWARAT T., SANITCHON J., PATTANAGUL W., THEERAKULPISUT P. Changes in anthocyanin content and expression of anthocyanin synthesis genes in seedlings of black glutinous rice in response to salt stress. Asian J. Plant Sci. 15, 56, 2016.

24. ALI H.M., ALMAGRIBI W., AL-RASHIDI M.N. Antiradical and reductant activities of anthocyanidins and anthocyanins, structure-activity relationship and synthesis. Food Chem. 194, 1275, 2016.

25. WANG J., HUANG R. Modulation of ethylene and ascorbic acid on reactive oxygen species scavenging in plant salt response. Front. Plant Sci. 10, 319, 2019.

26. TURHAN A., KUSCU H., OZMEN N., SERBECI M.S., DEMIR A.O. Effect of different concentrations of diluted seawater on yield and quality of lettuce. Chilean J. Agric. Res. 74 (1), 111, 2014.

27. ABDELGAWAD K.F., EL-MOGY M.M., MOHAMED M.I.A., GARCHERY C., STEVENS R.G. Increasing ascorbic acid content and salinity tolerance of cherry tomato plants by suppressed expression of the ascorbate oxidase gene. Agronomy 9, 51, 2019.

28. VAN DOORN W.G., KETSA S. Cross reactivity between ascorbate peroxidase and phenol (guaiacol) peroxidase. Postharvest Biol. Technol. 95, 64, 2014.

29. KRAM N.A., SHAFIQ F., ASHRAF M. Ascorbic acid-A potential oxidant scavenger and its role in plant development and abiotic stress tolerance. Front. Plant Sci. 8, 613, 2017.

30. BREŚ W., BANDURSKA H., KUPSKA A., NIEDZIELA J., FRĄSZCZAK B. Responses of pelargonium (Pelargonium $\times$ hortorum L.H. Bailey) to long-term salinity stress induced by treatment with different $\mathrm{NaCl}$ doses. Acta Physiol. Plant. 38, 26, 2016.

31. SLAMA I., M'RABET R., KSOURI R., TALBI O., DEBEZ A., ABDELLY C. Effects of salt treatment on growth, lipid membrane peroxidation, polyphenol content, and antioxidant activities in leaves of Sesuvium portulacastrum L. Arid Land Res. Manag. 31 (4), 1, 2017.

32. DANESHMAND F., ARVIN M.J., KALANTARI K.M. Physiological responses to $\mathrm{NaCl}$ stress in three wild species of potato in vitro. Acta Physiol. Plant. 32 (1), 91, 2010.

33. DE LA FUENTE B., LÓPEZ-GARCÍA G., MÁÑEZ V., ALEGRÍA A., BARBERÁ R., CILLA A. Evaluation of the bioaccessibility of antioxidant bioactive compounds and minerals of four genotypes of Brassicaceae microgreens. Foods 8 (7), 250, 2019.

34. DRABIŃSKA N., CISKA E., SZMATOWICZ B., KRUPA-KOZAK U. Broccoli by-products improve the 
nutraceutical potential of gluten-free mini sponge cakes. Food Chem. 267, 170, 2018.

35. BEN-OTHMAN S., JÕUDU I., BHAT R. Bioactives from agri-food wastes: Present insights and future challenges. Molecules 25, 510, 2020.

36. HOAGLAND D.T., ARNON D.I. The water culture method for growing plants without soil. Circular 347. University of California, College of Agriculture, Agricultural Experiment Station, Berkeley, California, 1938.

37. VALLEJO F., TOMÁS-BARBERÁN F.A., BENAVENTEGARCÍA A.G., GARCÍA-VIGUERA C. Total and individual glucosinolate contents in inflorescences of eight broccoli cultivars grown under various climatic and fertilisation conditions. J. Sci. Food Agric. 83 (4), 307, 2003.

38. WEATHERBURN M.W. Phenol hypochlorite reaction for the determination of ammonia. Anal. Chem. 39 (8), 971, 1967.

39. ZAGHDOUD C., CARVAJAL M., MORENO D.A., FERCHICHI A., MARTÍNEZ-BALLESTA M.C. Healthpromoting compounds of broccoli (Brassica oleracea L. var. italica) plants as affected by nitrogen fertilisation in projected future climatic change environments. J. Sci. Food Agric. 96 (2), 392, 2016.

40. FULEKI T., FRANCIS F. Quantitative methods for anthocyanins. J. Food Sci. 33 (1), 266, 1968.

41. RAHNESHAN Z., NASIBI F., MOGHADAM A.A. Effects of salinity stress on some growth, physiological, biochemical parameters and nutrients in two pistachio (Pistacia vera L.) rootstocks. J. Plant Interact. 13 (1), 73, 2018.

42. NAVEED M., SAJID H., MUSTAFA A., NIAMAT B., AHMAD Z., YASEEN M., KAMRAN M., RAFIQUE M., AHMAR S., CHEN J.-T. Alleviation of salinity-induced oxidative stress, improvement in growth, physiology and mineral nutrition of canola (Brassica napus L.) through calcium-fortified composted animal manure. Sustainability 12, 846, 2020.

43. CABOT C., SIBOLE J.V., BARCELÓ J., POSCHENRIEDER C. Lessons from crop plants struggling with salinity. Plant Sci. 226, 2, 2014.

44. REGINATO M., SOSA L., LLANES A., HAMPP E., VETTORAZZI N., REINOSO H., LUNA V. Growth responses and ion accumulation in the halophytic legume Prosopis strombulifera are determined by $\mathrm{Na}_{2} \mathrm{SO}_{4}$ and NaCl. Plant Biol. 16 (1), 97, 2014.

45. ASSAHA D.V.M., UEDA A., SANEOKA H., ALYAHYAI R., YAISH M.W. The role of $\mathrm{Na}^{+}$and $\mathrm{K}^{+}$ transporters in salt stress adaptation in glycophytes. Front. Physiol. 8, 509, 2017.

46. HUSSAIN B., LUCAS S.J., OZTURK L., BUDAK H. Mapping QTLs conferring salt tolerance and micronutrient concentrations at seedling stage in wheat. Sci. Rep. 7, $15662,2017$.

47. LEKSHMY S., SAIRAM R.K., KUSHWAHA S.R. Effect of long-term salinity stress on growth and nutrient uptake in contrasting wheat genotypes. Ind. J. Plant Physiol. 18 (4), 344, 2013.

48. SONG X., WANG S.M., JIANG Y. Genotypic variations in plant growth and nutritional elements of perennial ryegrass accessions under salinity stress. J. Amer. Soc. Hort. Sci. 142 (6), 476, 2017.

49. KHOLOVÁ J., SAIRAM R.K., MEENA R.C., SRIVASTAVA G.C. Response of maize genotypes to salinity stress in relation to osmolytes and metal-ions contents, oxidative stress and antioxidant enzymes activity. Biol. Plant. 53 (2), 249, 2009.

50. KUMAR R., LEE S.G., AUGUSTINE R., REICHELT M., VASSÃO D.G., PALAVALLI M.H., ALLEN A., GERSHENZON J., JEZ J.M, BISHT N.C. Molecular basis of the evolution of methylthioalkylmalate synthase and the diversity of methionine-derived glucosinolates. Plant Cell 31 (7), 1633, 2019.

51. SARABI B., BOLANDNAZAR S., GHADERI N., GHASHGHAIE J. Genotypic differences in physiological and biochemical responses to salinity stress in melon (Cucumis melo L.) plants: Prospects for selection of salt tolerant landraces. Plant Physiol. Biochem. 119, 294, 2017.

52. ASHRAFI E., RAZMJOO J., ZAHEDI M. Effect of salt stress on growth and ion accumulation of alfalfa (Medicago sativa L.) cultivars. J. Plant Nutr. 41 (7), 818, 2018.

53. ZAGHDOUD C., ALCARAZ-LÓPEZ C., MOTACADENAS C., MARTÍNEZ-BALLESTA M.C., MORENO D.A., FERCHICHI A., CARVAJAL M. Differential responses of two broccoli (Brassica oleracea L. var Italica) cultivars to salinity and nutritional quality improvement. Sci. World J. 2012 (2), 291435, 2012.

54. NOUCK A.E., TAFFOUO V.D., TSOATA E., DIBONG D.S., NGUEMEZI S.T., GOUADO I., YOUMBI E. Growth, biochemical constituents, micronutrient uptake and yield response of six tomato (Lycopersicum esculentum L.) cultivars grown under salinity stress. J. Agron. 15, 58, 2016.

55. KOPRIVA S., MUGFORD S.G., BARANIECKA P., LEE B.R., MATTHEWMAN C.A., KOPRIVOVA A. Control of sulfur partitioning between primary and secondary metabolism in Arabidopsis. Front. Plant Sci. 3, 163, 2012.

56. RODRÍGUEZ-HERNÁNDEZ M.C., MORENO D.A., CARVAJAL M., MARTÍNEZ-BALLESTA M.C. Genotype influences sulfur metabolism in broccoli (Brassica oleracea L.) under elevated $\mathrm{CO}_{2}$ and $\mathrm{NaCl}$ stress. Plant Cell Physiol. 55 (12), 2047, 2014.

57. MANSOUR M.M.F. Plasma membrane permeability as an indicator of salt tolerance in plants. Biologia Plantarum 57 (1), 1, 2013.

58. DAS S.K., PATRA J.K., THATOI H. Antioxidative response to abiotic and biotic stresses in mangrove plants: A review. Int. Rev. Hydrobiol. 101 (1-2), 3, 2016.

59. HE H., LIANG G., LI Y., WANG F., YU D. Two young microRNAs originating from target duplication mediate nitrogen starvation adaptation via regulation of glucosinolate synthesis in Arabidopsis thaliana. Plant Physiol. 164, 853, 2014.

60. MARINO D., ARIZ I., LASA B., SANTAMARÍA E., FERNÁNDEZ-IRIGOYEN J., GONZÁLEZ-MURUA C., APARICIO TEJO P.M. Quantitative proteomics reveals the importance of nitrogen source to control glucosinolate metabolism in Arabidopsis thaliana and Brassica oleracea. J. Exp. Bot. 67 (11), 3313, 2016.

61. JESCHKE V., WEBER K., MOORE S.S., BUROW M. Coordination of glucosinolate biosynthesis and turnover under different nutrient conditions. Front. Plant Sci. 10, 1560, 2019.

62. HESSE H., NIKIFOROVA V., GAKIERE B., HOEFGEN R. Molecular analysis and control of cysteine biosynthesis: integration of nitrogen and sulphur metabolism. J. Exp. Bot. 55 (401), 1283, 2004

63. GIGOLASHVILI T., KOPRIVA S. Transporters in plant sulfur metabolism. Front. Plant Sci. 5, 442, 2014. 
64. OUASSOU M., EL AMRANI A., MUKHAIMAR M. Mécanismes de biosynthèse et de régulation des glucosinolates. Eur. Sci. J. 15 (3), 313, 2019.

65. BOHINC T., TRDAN S. Environmental factors affecting the glucosinolate content in Brassicaceae. J. Food Agric. Environ. 10 (2), 357, 2012.

66. NEUGART S., HANSCHEN F.S., SCHREINER M. Glucosinolates in Brassica. In: Physiology of vegetable crops. Second edition. CAB International, Wallingford, UK, 15 (B), 389, 2020.

67. SARIKAMIŞ G., ÇAKIR A. Influence of salinity on aliphatic and indole glucosinolates in broccoli (Brassica oleracea var. italica). Appl. Ecol. Environ. Res. 15 (3), 1781, 2017.

68. TOLRÀ R.P., POSCHENRIEDER C., ALONSO R., BARCELÓ D., BARCELÓ J. Influence of zinc hyperaccumulation on glucosinolates in Thlaspi caerulescens. New Phytol. 151 (3), 621, 2001.

69. VARIYAR P.S., BANERJEE A., AKKARAKARAN J.J., SUPRASANNA P. Role of glucosinolates in plant stress tolerance. In: Emerging technologies and management of crop stress tolerance. Chapter 12. Elsevier 1, 271, 2014.

70. KAZEMI-DINAN A., SAUER J., STEIN R.J., KRÄMER U., MÜLLER C. Is there a trade-off between glucosinolate-based organic and inorganic defences in a metal hyperaccumulator in the field? Oecologia, 178 (2), 369, 2015.

71. BEEKWILDER J., VAN LEEUWEN W., VAN DAM N.M., BERTOSSI M., GRANDI V., MIZZI L., SOLOVIEV M., SZABADOS L., MOLTHOFF J.W., SCHIPPER B., VERBOCHT H., DE VOS R.C., MORANDINI P., AARTS M.G., BOVY A. The impact of the absence of aliphatic glucosinolates on insect herbivory in Arabidopsis. PLoS One 3 (4), e2068, 2008.

72. TORTORELLA S.M., ROYCE S.G., LICCIARDI P.V., KARAGIANNIS T.C. Dietary sulforaphane in cancer chemoprevention: the role of epigenetic regulation and HDAC inhibition. Antioxid. Redox Signal. 22 (16), 1382, 2015.

73. MARTÍNEZ-BALLESTA M., MORENO-FERNÁNDEZ D.A., CASTEJÓN D., OCHANDO C., MORANDINI P.A., CARVAJAL M. The impact of the absence of aliphatic glucosinolates on water transport under salt stress in Arabidopsis thaliana. Front. Plant Sci. 6, 524, 2015.
74. XIE Y.J., MAO Y., XU S., ZHOU H., DUAN X.L., CUI W.T., ZHANG J., XU G.H. Heme-heme oxygenase 1 system is involved in ammonium tolerance by regulating antioxidant defence in Oryza sativa. Plant Cell Environ. 38, 129, 2015

75. LIU Y., VON WIRÉN N. Ammonium as a signal for physiological and morphological responses in plants. J. Exp. Bot. 68 (10), 2581, 2017.

76. QIN C., QIAN W., WANG W., WU Y., YU C., JIANG X., WANG D., WU P. GDP-mannose pyrophosphorylase is a genetic determinant of ammonium sensitivity in Arabidopsis thaliana. Proc. Natl. Acad. Sci. U. S. A. 105 (47), 18308, 2008.

77. KOVÁČIK J., KLEJDUS B., BABULA P., JAROŠOVÁ M. Variation of antioxidants and secondary metabolites in nitrogen-deficient barley plants. J. Plant Physiol. 171 (3-4), 260, 2014

78. DOLIŃSKA B., OSTRÓŻKA-CIEŚLIK A., CABAN A., RIMANTAS K., LESZCZYŃSKA L., RYSZKA F. Influence of trace elements on stabilization of aqueous solutions of ascorbic acid. Biol. Trace Elem. Res. 150 (1-3), 509, 2012.

79. CHUNTHABUREE S., SAKUANRUNGSIRIKUL S., WONGWARAT T., SANITCHON J., PATTANAGUL W., THEERAKULPISUT P. Changes in anthocyanin content and expression of anthocyanin synthesis genes in seedlings of black glutinous rice in response to salt stress. Asian J. Plant Sci. 15 (3-4), 56, 2016.

80. ZHA J., KOFFAS M.A.G. Production of anthocyanins in metabolically engineered microorganisms: Current status and perspectives. Synth. Syst. Biotechnol. 2 (4), 259, 2017.

81. ZHANG F., WAN X., ZHENG Y., SUN L., CHEN Q., GUO Y., ZHU X., LIU M. Physiological and related anthocyanin biosynthesis genes responses induced by cadmium stress in a new colored-leaf plant "Quanhong Poplar". Agroforest. Syst. 88, 343, 2014.

82. SAI KACHOUT S., BEN MANSOURA A., ENNAJAH A., LECLERC J.C., OUERGHI Z., KARRAY BOURAOUI N. Effects of metal toxicity on growth and pigment contents of annual halophyte ( $A$. hortensis and $A$. rosea). Int. J. Environ. Res. 9 (2), 613, 2015. 